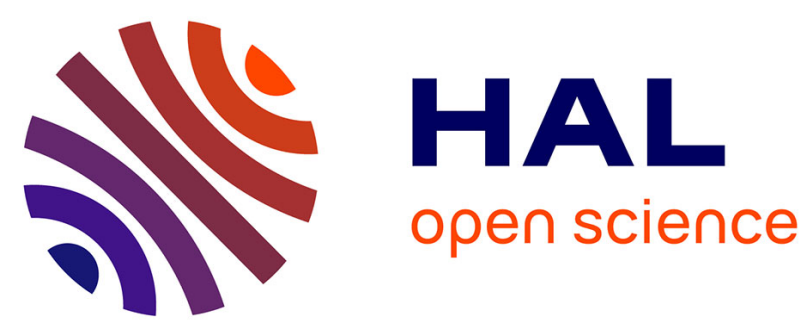

\title{
An evapotranspiration model driven by remote sensing data for assessing groundwater resource in karst watershed
}

Chloé Ollivier, Albert Olioso, Simon Damien Carrière, Gilles Boulet, Konstantinos Chalikakis, André Chanzy, Jean-Baptiste Charlier, David Combemale, Hendrik Davi, Christophe Emblanch, et al.

\section{To cite this version:}

Chloé Ollivier, Albert Olioso, Simon Damien Carrière, Gilles Boulet, Konstantinos Chalikakis, et al.. An evapotranspiration model driven by remote sensing data for assessing groundwater resource in karst watershed. Science of the Total Environment, 2021, 781, pp.146706. 10.1016/j.scitotenv.2021.146706 . hal-03203364

\section{HAL Id: hal-03203364 https://hal.inrae.fr/hal-03203364}

Submitted on 29 Apr 2021

HAL is a multi-disciplinary open access archive for the deposit and dissemination of scientific research documents, whether they are published or not. The documents may come from teaching and research institutions in France or abroad, or from public or private research centers.
L'archive ouverte pluridisciplinaire HAL, est destinée au dépôt et à la diffusion de documents scientifiques de niveau recherche, publiés ou non, émanant des établissements d'enseignement et de recherche français ou étrangers, des laboratoires publics ou privés. 


\section{Journal Pre-proof}

An evapotranspiration model driven by remote sensing data for assessing groundwater resource in karst watershed

C. Ollivier, A. Olioso, S.D. Carrière, G. Boulet, K. Chalikakis, A. Chanzy, J.-B. Charlier, D. Combemale, H. Davi, C. Emblanch, O. Marloie, N.K. Martin, N. Mazzilli, G. Simioni, M. Weiss

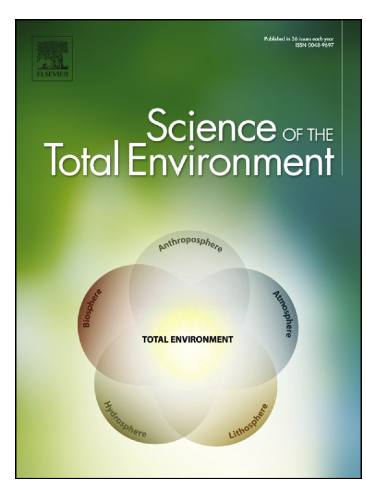

PII: $\quad$ S0048-9697(21)01774-5

DOI: $\quad$ https://doi.org/10.1016/j.scitotenv.2021.146706

Reference: $\quad$ STOTEN 146706

To appear in: $\quad$ Science of the Total Environment

Received date: $\quad 7$ January 2021

Revised date: $\quad 15$ March 2021

Accepted date: $\quad 19$ March 2021

Please cite this article as: C. Ollivier, A. Olioso, S.D. Carrière, et al., An evapotranspiration model driven by remote sensing data for assessing groundwater resource in karst watershed, Science of the Total Environment (2021), https://doi.org/ 10.1016/j.scitotenv.2021.146706

This is a PDF file of an article that has undergone enhancements after acceptance, such as the addition of a cover page and metadata, and formatting for readability, but it is not yet the definitive version of record. This version will undergo additional copyediting, typesetting and review before it is published in its final form, but we are providing this version to give early visibility of the article. Please note that, during the production process, errors may be discovered which could affect the content, and all legal disclaimers that apply to the journal pertain.

(C) 2021 Elsevier B.V. All rights reserved. 


\section{An evapotranspiration model driven by remote sensing data for}

\section{assessing groundwater resource in karst watershed}

C. Ollivier ${ }^{1,2}$, A. Olioso ${ }^{2}$, S.D. Carrière ${ }^{2,3}$, G. Boulet $^{1}$, K. Chalikakis $^{2}$, A. Chanzy ${ }^{2}$, J-B. Charlier ${ }^{4}$, D. Combemale ${ }^{2,5}$, H. Davi ${ }^{6}$, C. Emblanch ${ }^{2}$, O. Marloie ${ }^{6}$, N. K. Martin ${ }^{6}$, N. Mazzilli ${ }^{2}$, G. Simioni ${ }^{6}$, M. Weiss $^{2}$

${ }^{1}$ CESBIO, Université de Toulouse, IRD, CNRS, UPS, CNES, Toulouse, France

${ }^{2}$ EMMAH, INRAE, Avignon Université, Avignon, France

${ }^{3}$ METIS, Sorbonne Université, UPMC, CNRS, EPHE, Paris, France

${ }^{4}$ BRGM, Université Montpellier, Montpellier, France

${ }^{5}$ SILVA, Université de Lorraine, AgroParisTech, INRAE, Nrr, $-v$, I rance

${ }^{6}$ URFM, INRAE, Centre de recherche PACA, Avignon, r.u.'ct

\section{Highlights}

- SimpKcET (Simple Crop coefficier $i t r$ t.apotranspiration) reproduces the dynamics of ET of a wide range of vegetation c ver

- A better estimation of ET with $^{\text {th }} S_{1}, n$ PKCET of a large watershed improves simulations of its outflow discharges.

- The shading of the soi by the presence of pieces of rock on its surface limits the evaporation of the coil, his process plays a major role in the estimation of ET in karst areas.

- Despite the simpı - ity of the assumptions, the estimates are below $0.5 \mathrm{~mm} \cdot \mathrm{d}^{-1}$. 


\section{Graphical abstract}

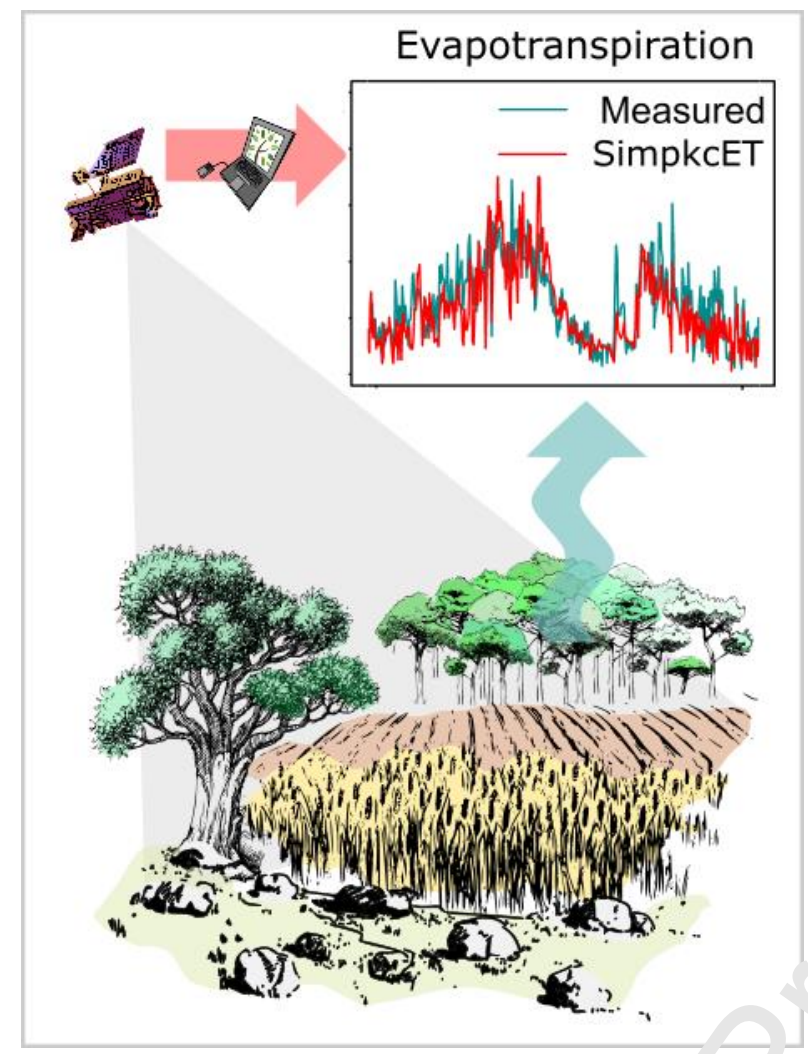

\section{Abstract}

Aquifer recharge may depend $n$. ᄀinly on the difference between precipitation and evapotranspiration. Hydrologi 7 l models used to estimate groundwater reserves use evapotranspiration models tha are mainly determined by climate demand. In particular, mechanisms of plant +ra.' 'spi ation are neglected, although transpiration constitutes $70 \%$ of evapotranspiration. This $i$, problematic when considering karst watershed, which are poorly documented at the interface between soil and atmosphere where vegetation and soil properties control water flows. To fill this gap, we propose an evapotranspiration model that integrates the processes of plant transpiration and soil evaporation. The dynamics of vegetation is evaluated using the Enhanced Vegetation Indexes from the Terra and Aqua Moderate Resolution Imaging Spectroradiometers. The soil evaporation calculation account for the impact of coarse elements at soil surface. The "Simple Crop coefficient for Evapotranspiration" (SimpKcET) model is tested at flux tower sites over forest of FontBlanche, Puechabon and the agricultural area of Avignon. The simulated daily 
evapotranspirations are very close to the observations (RMSE $\sim 0.5 \mathrm{~mm} \mathrm{~d}-1$ ), while the model is simple compared to other models proposed in the literature. The SimpKcET is implemented in a karst hydrological model to evaluate the impact of evapotranspiration estimation on the aquifer flow rate simulation. This approach is applied to the vast watershed of Fontaine de Vaucluse. In comparison to the water bucket model that is frequently used in karst models, SimpKcET provide ET simulations that are more in line with ET processes. A cross wavelet analysis highlighted the improvement of the simulated recharge and observed flow rate relationship brought by the consideration of evaporation and transpiration processes. The use of remote sensing data elated to plant activity makes it possible to propose a parsimonious model that can be ar sin d co all types of vegetation (agricultural, natural, mixed forest) and that can be transf $-11 x$ to other karst models.

Keywords: Evapotranspiration; Fraction cover; Hydroln Iณ.1 modelling, Karst, Recharge

\section{Introduction}

An accurate knowledge of aquifer recha ge s decerminant for water resources assessments. Aquifer recharge is the quantity of water which supplies underground reserves. It mainly results from the infiltrated amou $\|$ or the difference between precipitations $(P)$ and evapotranspiration (ET), that bo+' ${ }^{+}{ }^{\prime}$ ıy in space and time. ET is a difficult term to quantify [Shuttleworth 2007, Farahani st aı. 2007]. Thus, a poor estimate of ET can have a strong impact on the assessment of the spatial distribution of aquifer recharge. When considering karst aquifers that have -om Jlex hydrodynamic properties, knowledge of the distribution of evapotranspiration and $r \epsilon=$ harge is even more difficult.

ET is the sum of water transpired by the plants and the water evaporated by other surfaces as soil surface and free water [Shuttleworth 2007]. It depends on many factors related to climate, vegetation and soil. ET is a major process in the water cycle. It consumes around two-thirds of the world terrestrial rainfall according to McDonald [1961] and Brutsaert [1982]. Despite its importance, ET is still poorly quantified as it is complex and expensive to measure [Rana and Katerji, 2000, Shuttleworth, 2008]. ET processes are difficult to model as the variability of ecosystem response to climate and soil moisture is large. ET models 
intercomparing exercises [Grippa et al., 2017, Kimball et al., 2017] show that simulated ET exhibit large differences from one model to another.

In most karst hydrogeological studies, ET processes are highly simplified. In particular, models used to evaluate water resources often neglect the transpiration dynamics of plants [Hartmann et al., 2015, Hartmann et al., 2012, Oudin, 2004]. This may have large implications on the dynamics of simulated ET and thus, simulated recharge. In the current context of global changes, it is important that the interactions between land cover and climate evolutions can be described in a realistic way [Breshears et al., 2005, Cramer et al., 2001, Liu et al., 2019]. Therefore, it is important to model ${ }^{-T}$ that represent the most important term of water cycle after Fisher et al. [2017] anc ET 's at the heart of climate land surface interactions.

Hydrological models are constructed from a water oalc nce equation, assuming that water inputs (mainly due to precipitations) are equilibr - ced by water outputs (ET, runoff from streams and springs) and storage variatiors. In many cases, adjustment variables for obtaining this equilibrium are groun',wa er stock and ET. The estimation of ET in hydrogeological models is often constrainet by the optimisation of the rainfall-discharge relationship. For instance, Oudin et a. $[<205 a, b]$ studied the importance of ET formulation in numerous rainfall-discharge ... na is. They showed that even large variations in ET produced only small variation: in simulated flow rate. Actually, the calibration of model parameters compensated for $\mathrm{l}$.e differences in ET inputs. It should be noted that these models were not accnur ing 'or spatial variations of water flows, which has an impact on the simulation of global flow Using a distributed model, Ollivier et al. [2020] showed that the location of precipitation has an impact on simulations of karst aquifer discharges. They argued that the spatial distribution of ET components should also have a significant impact and that an accurate estimation of both temporal evolution of ET and its variation in space could improve the simulation of flow rate. One of the improvements in hydrogeological modelling of karst systems would be the implementation of a model that better describes evapotranspiration and at the same time improves the relation between rainfall and discharge in karstic hydrosystems. 
Direct ET measurements can be performed at local scale. The data from a large number of micrometeorological tower sites all over the world are compiled in the FLUXNET database [Baldocchi et al., 2001, Chu et al., 2017]. Micrometeorological tower relies on eddy covariance methods to measure the exchanges of carbon dioxide, water vapor and energy between terrestrial ecosystems and the atmosphere. They provide ET estimates at a specific location, for a given type of cover. These measures are strongly influenced by local environmental factors, and extrapolation to regional scales is difficult. However, these measurements provide insights into the daily dynamics of ET for specific ecosystems.

Spatially distributed information on vegetation activity and EI nay be provided by satellite remote sensing. For example, the MODIS (Moderate Resolut on naging Spectroradiometer) sensors on board of the Terra and the Aqua satellites ar vie ving the entire Earth's surface every day, acquiring data that are used to monitor vernta ion and ET at spatial resolutions of $1 \mathrm{~km}$ [e.g. Allies et al., 2020, Gallego-Elvira et al., 2u:?, Mu et al., 2007]. In particular, the combination of the bands specific to the plant a'tivity allows the calculation of vegetation indexes such as the Normalized Differf...-e '/egetation Index (NDVI) and the Enhanced Vegetation Index (EVI) [Huete et al., : 110, 2002, 1994] and thus the monitoring of vegetation. Operational products basec in remote sensing data, such as GLEAM [Martens et al., 2017] or MOD16 [Mu et al., 200i, 2(11] are providing ET estimates at different scales (30 $\mathrm{km}$ every day and $1 \mathrm{~km}$ for $8 \mathrm{r}_{\mathrm{a}}, \mathrm{c}$ periods, respectively). These products could be used for hydrological studies. Howeve, thiey are still imperfect as they have drawbacks as either low spatial resolution, low ti « resolution or a strong uncertainty [e.g. Hu et al., 2015, Jung et al., 2019, Moreira et al., 'Uı9, Shen et al., 2017, Zhang et al., 2018].

While remote sensing information is intensively used in various research fields, the integration of remote sensing data in groundwater modelling is not a very common practice yet In order to evaluate the benefit for water resource evaluation of an accurate estimation of ET, we proceed as follows:

- to propose an evapotranspiration model that enables a consistent representation of main processes (vegetation transpiration and soil evaporation),

- to develop an efficient model with available parameters for all types of vegetation, 
- to evaluate the consistency of the proposed model against commonly used models into hydrogeological models of karst hydrosystem.

In this article we propose a remote sensing driven ET model that considers the transpiration dynamics of natural and agricultural vegetation cover and the evaporation of stony soils. The model can easily be integrated into hydrological models, herein called SimpKcET. The dynamics of vegetation covers is evaluated using vegetation indexes from MODIS dataset. We tested the SimpKcET model over three different types of vegetation cover for which ET measurements are available: two forest sites mostly constituted by sempervirens trees (Quercus ilex L. and Pinus halepensis Mill.) and a wheat crop sit .

The SimpKcET model was integrated into a spatially $a_{1}{ }^{++r}$. outed hydrological model dedicated to karst catchments in a second step (the KaF alv ${ }^{\prime \prime}$ model developed by Ollivier et al. [2020]) for simulating water flows of karst aquif $: r$. ihe test site is the karstic aquifer of the Fontaine de Vaucluse, located in Southeast of F. anc.. This aquifer has a watershed area of $1162 \mathrm{~km}^{2}$ mainly occupied by forests and $n \exists \mathrm{ral}$ environments. The daily simulated ET of Fontaine de Vaucluse watershed is cor,pa ed with ET simulated with an usual ET model often employed by hydrological modelling c: karst aquifer. The influence of the ET model on the flow simulation is evaluated witr. Wciselet analysis.

\section{Evapotranspiration mu del and karst model}

\subsection{Usual evapotran pir tion model in karst groundwater models}

Surface of karst syster. . an be very heterogeneous, for instance karstic features induce an important variation of soils properties. Soils can be thick and clayey in dolines (enclosed karst depressions, called also sinkholes in some cases, e.g. Ford and Williams 2007), thin and stony on slopes, and discontinuous when soil fills the deepest forms of lapiaz (a network of chiseling on the surface of compact carbonate, which can be from a few $\mathrm{mm}$ to $10 \mathrm{~m}$ deep; it is due either to the dissolution or erosion). Karstic features indicate the presence of an underlying karst aquifer with extensive solution channels crossing the unsaturated zone. Compared to common porous aquifers, the important anisotropy of the hydrodynamic properties of the unsaturated zone of the karst, limits the possibility to model subsurface 
flows and exchanges with the atmosphere with classical diffusivity equations. Therefore, karst is often represented with lumped models. Lumped approaches conceptualize the physical processes at coarse scale without modelling spatial variability explicitly. They are mostly based on linear or nonlinear relationships between rainfall and discharge [Fleury et al., 2007, Tritz et al., 2011]. The spatial variability of selected components can be represented with semi-distributed lumped models. The modelled hydrosystem is then subdivided into entities assumed to be homogeneous for the dominant characteristics [Kite and Kouwen, 1992]. This type of modelling is used to model karstic hydrosystems by considering different sources of heterogeneity such as pr(cipitation regime and runoff processes [Bailly-Comte et al., 2012], transfer dynamics w.thın the unsaturated zone [Ladouche et al., 2014, Ollivier et al., 2020] or evapotrans'ıl ‘ Ion [Jódar et al., 2018, Sarrazin et al., 2018]. In common lumped karst models, the ground is represented by a single overflow storage (Figure 1). The actual evapotransp: 'atic ? (ET) is a direct function of the soil moisture state, and recharge $\left(Q_{H}\right)$ occurs only when the infiltration water exceeds the soil available water capacity (SAWC) [e.g. Fleury e aı., ¿007, Rahman and Rosolem, 2017, Tritz et al., 2011, Ollivier et al., 2020]. It $t^{t}$.e present work, this simple modelling of

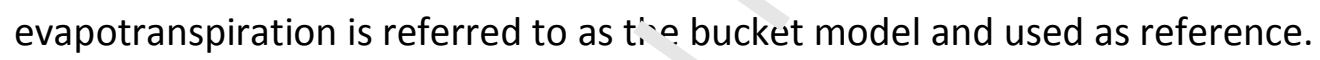

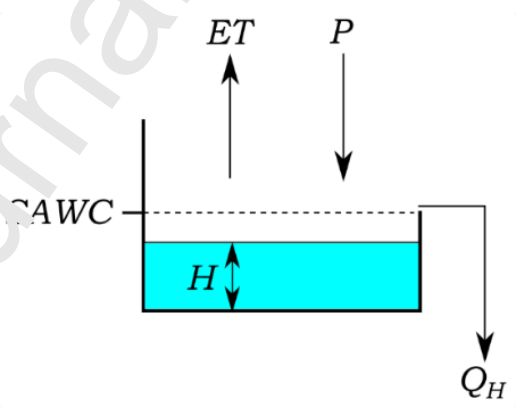

Figure 1: Schema of the bucket model of evapotranspiration

$$
\begin{gathered}
\mathrm{ET}=\left\{\begin{array}{cc}
\mathrm{H}+\mathrm{P}, & \text { if } \mathrm{H}+\mathrm{P}<\mathrm{k} . \mathrm{ETp} \\
\mathrm{k} . \mathrm{ETp}, & \text { if } \mathrm{H}+\mathrm{P} \geq \mathrm{k} . \mathrm{ETp}
\end{array} \#(1)\right. \\
\mathrm{Q}_{\mathrm{H}}=\left\{\begin{array}{cc}
0, & \text { if } \mathrm{H}+\mathrm{P}-\mathrm{ET}<\mathrm{SAWC} \\
\mathrm{P}-\mathrm{ET}, & \text { if } \mathrm{H}+\mathrm{P}-\mathrm{ET} \geq \mathrm{SAWC}
\end{array} \#(2)\right. \\
\frac{\mathrm{dH}}{\mathrm{dt}}=\left\{\begin{array}{cc}
\max (\mathrm{P}-\mathrm{ET}, 0), & \text { if } \mathrm{H}<\mathrm{SAWC} \\
\mathrm{P}-\mathrm{ET}-\mathrm{Q}_{\mathrm{H}}, & \text { if } \mathrm{H} \geq \mathrm{SAWC}(3)
\end{array}\right.
\end{gathered}
$$


where ET is the daily evapotranspiration (in $\mathrm{mm} \cdot \mathrm{d}^{-1}$ ), P the daily precipitation (in $\mathrm{mm} \cdot \mathrm{d}^{-1}$ ), ETp the daily potential evapotranspiration corresponding to climate demand (in mm. $\mathrm{d}^{-1}$ ). $\mathrm{H}$ is the water level of the reservoir (in $\mathrm{mm}$ ), $\mathrm{Q}_{H}$ stands for daily infiltration and runoff (in $\mathrm{mm}$ ), SAWC is the soil available water capacity (in $\mathrm{mm}$ ). Evapotranspiration depends on climatic demand with a scaling coefficient (k). As in many hydrological karst models, Ollivier et al [2020] set the scaling coefficient $k$ to 1 [e.g. Fleury et al., 2007, Messerschmid et al., 2020]. ETp may be calculated with different methods depending on the study. Here we used the socalled reference evapotranspiration ETo as described in section 2.2

However, several studies proposed that $\mathrm{k}$ is not constant dep - nding on surface conditions. For instance, Tritz et al. [2011] expressed k as a function of t me, Charlier et al. [2012], Hartmann et al. [2012] and Perrin et al. [2003] as a func: ion if reservoir fill rate in order to represent the soil resistance to evaporation. Coefficinnt :' may also simulate a reduction in ET/ETo as the transpiration capacity of plants may : - limited by plant development and plant access to available water in the soil [Sarra ir $\epsilon^{+}$. al., 2018, Jódar et al., 2018]. Sarrazin et al. [2018] implemented a physically $r$-eu evapotranspiration equation into a semidistributed lumped model of epikarst. 'ney used the average leaf area index and an extinction coefficient to estimate lie canopy cover fraction and to separate the evapotranspiration flux into transpir ti, nn and evaporation. Their model depends on many parameters for describing the vesetation (LAI, vegetation height, stomatal resistance) and the soil (soil resistance, storas ${ }^{\circ}$ capacity of soil layers), which limits the application at large scale. However, their wrin nuints out that better modelling of evapotranspiration in karst hydrological models is reeded to forecast the impact of vegetation change on resources. Jódar et al. [2018] showed that remote sensing can be used to assess the spatial variations of $\mathrm{k}$ in relation to plant development.

\subsection{Remote sensing-based model to estimate evapotranspiration, SimpKcET}

In this study we proposed to improve the simulation of ET by using the SimpKcET model which considers that ET depends on the climatic demand, the dynamics of the vegetation, which is monitored using remote sensing data, the level of soil moisture in the root zone and the fraction of rocks and coarse elements in the surface soil layer. Standard evapotranspiration models (like the FAO56 method) consider the lack of evaporation from 
soils under plant canopies, but they neglect the reduction of evaporation from soils by pebbles and rocks in the surface layer. In the case of soils growing on carbonate bedrock, the presence of pebbles or denudated rocks is significant [Bottner 1971, Godard et al. 2016] as shown for instance on the aerial photography in Appendix C.

SimpKcET basically follows the "dual crop coefficient (under non-standard conditions)" proposition given by Allen et al. [1998] with some simplifications. These simplifications were justified by the low level of information available for computing ET from natural areas (ecosystem composition and heterogeneity, soil characteristics...). In comparison, information related to agricultural vegetation is more abundan hecause they are needed for the evaluation of water requirements, in particular for irı gatı on management, and crop productivity. ET is thus expressed using the following equ. tior

$$
\mathrm{ET}=\mathrm{k}_{\mathrm{C}} * \mathrm{ETo}:(4)
$$

The coefficient $k_{c}(-)$, equivalent to the classir. crop coefficient, was composed of two terms, $\mathrm{k}_{\mathrm{T}}(-)$ the canopy transpiration coeffici'nt aı $\mathrm{k}_{\mathrm{E}}(-)$, the soil evaporation coefficient:

$$
\mathrm{k}_{\mathrm{C}}=\mathrm{r}_{\mathrm{C}}+\mathrm{k}_{\mathrm{E}} \#(5)
$$

The reference evapotranspiration (ET.) c r rresponds to ET that would be produced by a well irrigated grass surface. ETo is co' " N ${ }^{\top} / \omega d$ using the Penman-Monteith equation as proposed by Jensen et al. [1990] and Al!' $n$ eı al. [1998]. Other equations such as Penman equation or Hargreaves equation have heer widely used to represent climatic demand [e.g. Doorenbos and Pruitt, 1977, Harore 'ves and Samani, 1985, Oudin et al., 2005b, Trajkovic, 2005], but the Penman-Monteith equat on is considered as better suited for accounting for vegetation processes [Allen et al. 1998, Hargreaves and Allen, 2003]. It expresses ETo with the following formula:

$$
\text { ETo }=\frac{\Delta *\left(\mathrm{R}_{\mathrm{n}}-\mathrm{G}\right)+\rho_{\mathrm{a}} * \mathrm{c}_{\mathrm{p}} * \frac{\mathrm{VPD}}{\mathrm{r}_{\mathrm{a}}}}{\mathrm{L}\left[\Delta+\gamma *\left(1+\frac{\mathrm{r}_{\mathrm{s}}}{\mathrm{r}_{\mathrm{a}}}\right)\right]} \#(6)
$$

where $\Delta$ is the slope of the vapor pressure saturation curve, $\rho_{\mathrm{a}}$ the density of the air, $\mathrm{c}_{\mathrm{p}}$ the specific heat of the air at constant pressure, $\gamma$ the psychrometric constant and $\mathrm{L}$ the latent heat of vaporization. The term $r_{a}$ represents the aerodynamic resistance while the term $r_{s}$ is 
the surface resistance which corresponds to the integration of stomatal and soil surface resistance. $R_{n}$ and $G$ are the net radiation and the ground heat flux. Their difference represents the energy available for ET. VPD is the Vapor Pressure Deficit in the air above the surface. Specific values of the parameters to compute the resistance terms and the available energy were defined for reference types of canopy such as clipped grass or alfalfa stand. A full description of the ways to use this equation for reference evapotranspiration computing is given by Allen et al. [1998].

The canopy transpiration coefficient $\left(\mathrm{k}_{\mathrm{T}}\right)$ is related to both vegetation amount and water stress. We use the fraction of vegetation cover $f_{\text {cover }}$ that can $k$ - easily derived from remote sensing data using vegetation indices or neural network $n$ ode $s$ as a proxy of vegetation amount. The canopy transpiration coefficient $k_{T}$ can thus l e e> pressed as:

$$
\mathrm{k}_{\mathrm{T}}=\mathrm{f}_{\text {cover }} * \mathrm{k}_{\mathrm{s}} * \mathrm{k}_{\mathrm{Tx}}:(\%)
$$

where $k_{T x}$ is the maximum value of the canop: : ranspiration coefficient and $k_{s}$ the water stress depending on soil moisture (Figure 2) Classical values for $\mathrm{k}_{\mathrm{Tx}_{\mathrm{x}}}$ range between 0.8 and 1.5 depending on the vegetation type nd the definition of ETo. Strong relations between $\mathrm{f}_{\text {cover }}$ and $\mathrm{k}_{\mathrm{T}}$ (or $\mathrm{k}_{\mathrm{C}}$ when soil evapora: in was insignificant) were obtained in various studies [e.g. Heilman et al., 1982, Melton e' $\mathrm{a}^{\prime}$., ' ग12] and analysed theoretically by Choudhury et al. [1994] and Allen and Pereira [2n)9]. Their results showed that, even if the $k_{T}\left(f_{c o v e r}\right)$ relation can be curvilinear, a linear r' rationship can be generally considered as an acceptable approximation. The water siners coefficient $k_{s}$ is expressed as a function of the root zone water availability as $\mathrm{p}-\mathrm{es} \cdot \mathrm{nt} \mathrm{d}$ in Figure 2 . The root zone water availability is defined as the ratio of available wate ${ }^{+}$J SAWC representing the maximum amount of water that can be available for ET. The water stress coefficient is set to 1 for root zone water availability larger than $2 / 3$. Below this threshold, it linearly decreases to zero with the water availability. 


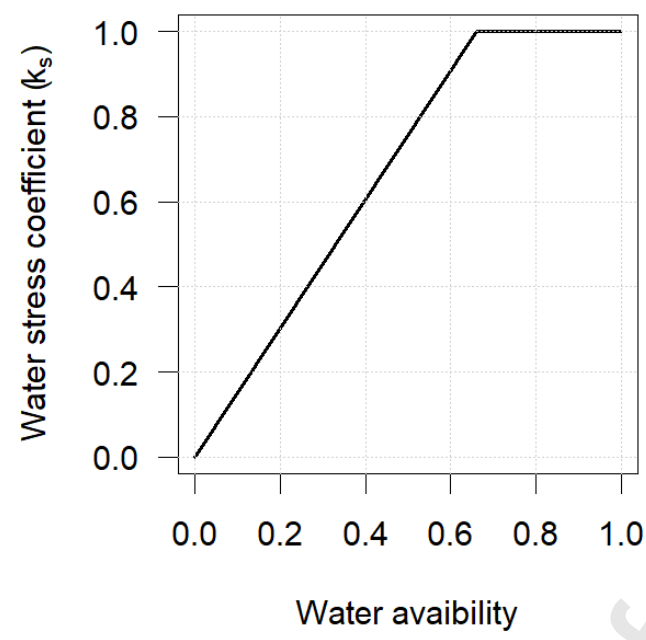

Figure 2: Relationship between the water stress coefficien $\left(k_{s}\right)$ and the root zone water availability.

The soil evaporation coefficient $k_{E}$ accounts for the evc puration processes that occur over the fraction of soil that is not covered with vegetat; on i- $\left.f_{\text {cover }}\right)$, bulk elements and rocks (1$\left.f_{\text {rocks }}\right)$ :

$$
\mathrm{k}_{\mathrm{E}}=\left(1-\mathrm{f}_{\text {cove }}\right) \cdot\left(1-\mathrm{f}_{\text {rocks }}\right) * \mathrm{k}_{\mathrm{ini}} \#(8
$$

where the coefficient $k_{\text {ini }}$ is equivalent $\imath$ the initial stage crop coefficient defined by Allen et al. [1998] and Allen et al. [2005] fur representing the soil evaporation at the beginning of crop growth. It expresses the a $a_{r}$ acity of the soil surface layer to evaporate depending on the climatic demand (ETo) anc' the frequency of rainfall events (Figure 3). It is expressed as:

$$
\mathrm{k}_{\mathrm{ini}}=\left[1+\left(\frac{\mathrm{ETo}}{\mathrm{a}}\right)^{\mathrm{b}}\right]^{-1} \#(9)
$$

where $a$ is the number of rainy days in the last 20 days and $b$ is a coefficient expressing the availability of water to evaporation. This parameter was calibrated so that the shape of $k_{\text {ini }}$ globally matches the curves presented in Allen et al. [1998]. Its value ranged between 1 and 5.

Once again, more complex descriptions of $\mathrm{k}_{\mathrm{s}}$ and $\mathrm{k}_{\mathrm{ini}}$ were proposed by Allen et al. [1998] and Allen et al. [2005] and for example used by Jódar et al. [2018]. However, to be applied, they require a precise knowledge of plant types and soil types which is not usually available over large areas or for complex systems, such as soil in karst systems and epikarst. 


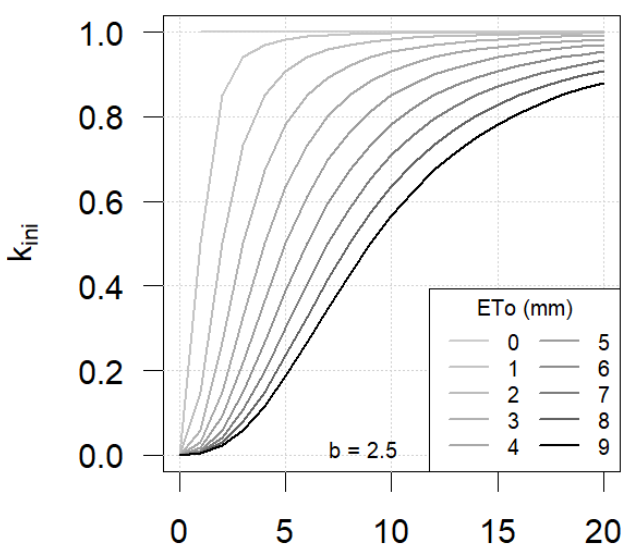

Number of rainy days (a)

Figure 3: Average $k_{\text {ini }}$ as a function of the climatic demand (ETO) a d the number of rainy days during the last 20 days (a) after Allen et al. [1998].

\subsection{The karst model}

The main characteristic of karst systems is $\bar{c} .1 \mathrm{~g}$ ) degree of heterogeneities. The karst network features act as pipes and enablf a $a p \cdot \gamma$ infiltration and then percolation of surface water to groundwater table. The karst $n t$. vork is developed through carbonate rock with very low hydraulic permeability. An important amount of water undergoes diffuse percolation through carbonate alterf $\downarrow$ by fractures, diaclases and faults. The strong heterogeneity of karst formations makes it difficult to apply a distributed model to estimate the spatial distribution of watc " resources [Hartmann et al., 2014]. The Karst Recharge and discharge Model (KaRan,el) vas developed from the consideration that knowledge of karst aquifer properties deci:ases with depth [Ollivier et al., 2020]. KaRaMel simulates the distribution of terrestrial water balance using a daily temporal resolution. Its structure considers infiltration of rainfall and snowmelt, ET and downward percolation from the upper soil layer to the underlying aquifer. Underground flows are represented with coarse resolution by a lumped model. A basic description of parameters of KaRaMel is given in the appendix $A$.

The terrestrial water balance is controlled by the soil available water capacity (SAWC). SAWC is mapped over the watershed after soil measurements and a spatial interpolation method based on the principles of digital soil mapping [McBratney et al., 2003]. Underground flows 
are discretized into two classes: rapid and slow. The proportion of rapid to slow flows is controlled by the intrinsic vulnerability indices, based on the assumption that rapid flows through the vadose zone are dominant on areas with high karst features density. The consideration of these two levels of distribution of the parameters allows the simulation of the spatial variability of the hydrosystem stocks and the discharge at the aquifer outlet. Different ET models may be easily implemented into KaRaMel. We thus use KaRaMel to enable the evaluation of the consistency of the simulated input-output relationship of the karst system for the two different ET models: the bucket model (ETbu) and the SimpKcET model (ETsimp).

\section{Data and model implementation}

\subsection{Test sites}

SimpKcET was first evaluated over three loca' s'its equipped with a micrometeorological tower and in a second time at the leve $\mathcal{f}^{f_{1}} \mathrm{t}_{1}$. karst aquifer of the Fontaine de Vaucluse system, the local sites cover different laı ' uses under a Mediterranean climate. Two sites are forested areas: one oak forest, c.e oak and Aleppo pines mixed forest, both sites develop on carbonate rocks. The thir $d$, ite is a crop field (wheat) and is in an alluvial plain. The three local sites differed froı, the Fontaine de Vaucluse watershed by lower elevations and by being closer to the sea ${ }^{-i d t}$ (Figure 4), which implied significant differences in rainfall and ETo (Appendix D).

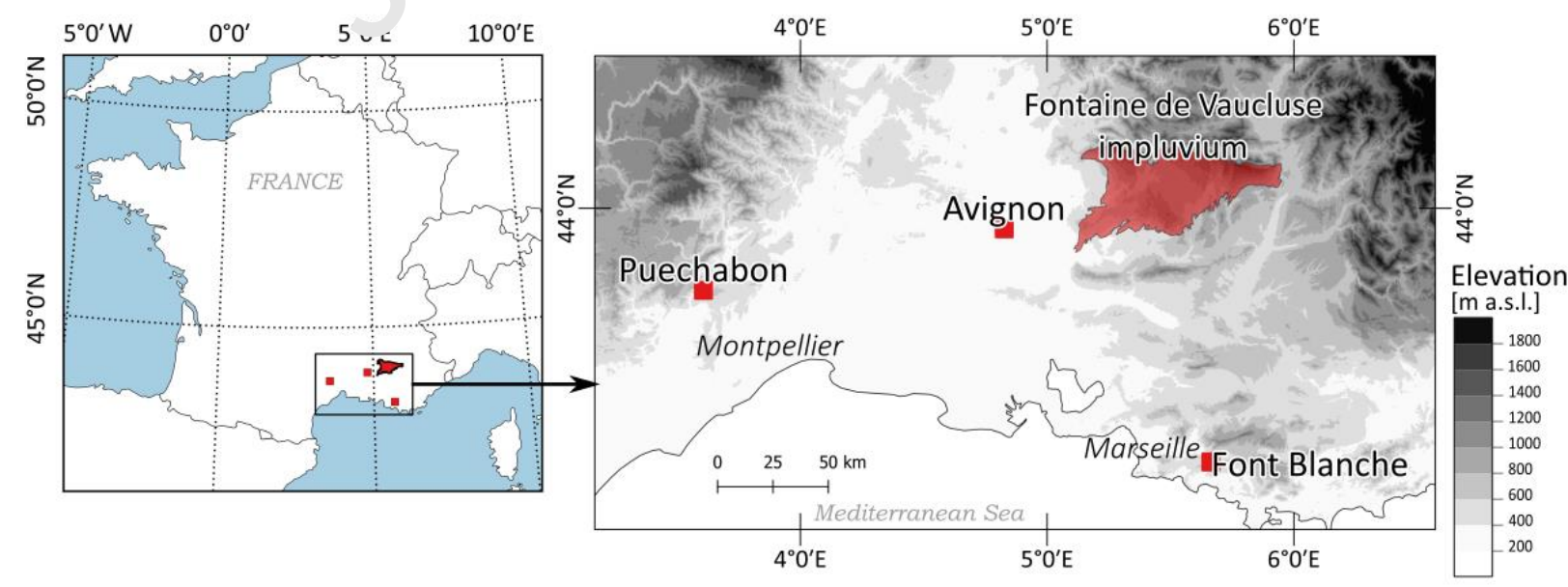


Figure 4: The three test sites equipped with micrometeorological tower (red square) and the Fontaine de Vaucluse watershed (red polygon), located South-East of France

\subsubsection{The Font-Blanche forest}

The Font-Blanche long-term experimental monitoring site is located in a mixed Mediterranean forest in south-eastern France $\left(43^{\circ} 14^{\prime} 27^{\prime \prime} \mathrm{N}, 5^{\circ} 40^{\prime} 45^{\prime \prime} \mathrm{E}\right.$; altitude $\left.425 \mathrm{~m}\right), 20$ $\mathrm{km}$ east of Marseille (Figure 4). It is dominated by Aleppo pines (Pinus halepensis) in the upper tree stratum (average height, $13 \mathrm{~m}$ ) and holm oak (Quercus ilex) in the intermediate tree stratum (average height, $5 \mathrm{~m}$ ). The understorey is composed of different species, mainly narrow-leaved mock privet (Phillyrea angustifolia) and ker.as oak (Quercus coccifera) [Girard et al., 2012]. The climate is Mediterranean with hot, dry ummers. The mean annual temperature and precipitation were $14^{\circ} \mathrm{C}$ and $701 \mathrm{~mm}$. re: pectively, between 2008 and 2017. The bedrock is karstified Cretaceous limestorn the soil has a maximum depth of around $50 \mathrm{~cm}$, and a volumetric rock fraction of abou. $5 \%$ at the top, and up to $90 \%$ at the bottom.

Font-Blanche is part of the Integrated $r$ ark on ubservation System (ICOS) and the Analysis and Experiments on Ecosystems (AnaEE-Fra ce, see Clobert et al. [2018]) networks. The site is equipped with a $17 \mathrm{~m}$ eddy-covari-. re ? $\mathrm{ux}$ tower on top of which meteorological variables (including radiation, rainfall, tem s raiure, vapour pressure deficit), and carbon, water and energy fluxes are continuously nor.tored at 30 min intervals.

The available water caparit, f', plants used by Marie and Simioni [2014] in a modelling study was set to $145, \sim m_{1} . \Delta$ more recent estimate based on the analysis of eddy covariance fluxes during the sumr $\sim$. period is about $170 \mathrm{~mm}$ [Simioni et al. 2016]. The stone-free fine fraction of the soil is a homogeneous silty clay loam that contains around a third of the available water capacity (as observed from soil pit). The remaining extractable water is located in the subsoil (bedrock), within fractures and clay pockets.

\subsubsection{The Puechabon forest}

The Puechabon forest is located $35 \mathrm{~km}$ northwest from Montpellier $\left(43^{\circ} 75^{\prime} \mathrm{N}, 3^{\circ} 6^{\prime} \mathrm{E}, 250 \mathrm{~m}\right.$. a.s.l.). The site and the data were described by Rambal [1992, 1993], Rambal et al. [2003], Allard et al. [2008] and Rambal et al. [2014]. It is located over a flat plateau and it is mainly composed of holm oak (Quercus ilex) of $5 \mathrm{~m}$ high. The understory is composed of sparse 
scrubs of $2 \mathrm{~m}$ height. The soil layer is developed into a limestone altered zone where the fine earth is composed of silt (35\%), clay (39\%) and sand (26\%). The soil thickness ranges from 0 to $0.9 \mathrm{~m}$ but the soil content has a high proportion of stones and rocks ( $75 \%$ between 0 and $0.5 \mathrm{~cm} ; 90 \%$ or more below). The plant roots are developed through soil pockets and explored limestone fissures. A large fraction of the root mass is found in the first $0.5 \mathrm{~m}$ but some roots have been found down to a depth of $4.5 \mathrm{~m}$.

The site was part of the CARBOEUROPE European project and the data between 2000 and 2014 are available within the FLUXNET database ORNLDAAC2017. ET was derived from eddy covariance measurements of latent heat flux.

\subsubsection{The Avignon crop site}

Avignon crop site is located close to Avignon city $\left(43^{\circ} \angle 44_{1}^{\prime}, \circ^{\circ} 5^{\prime} \mathrm{E}, 32 \mathrm{~m}\right.$ a.s.l.). The site and the measurement setup were described by Garrigur s e. al. [2018, 2015]. The crop rotation consists in a succession of winter crops such as whe it and summer crops as maize or sunflower. During the inter-crop, no vegetatio, is ısually present, the soil being ploughed sometime after the harvest. The soil is $v$ ell levtioped with a thickness between 1.3 and 2.0 $\mathrm{m}$. Its fine fraction is composed by clay (3,\%), sand (14\%) and silt (53\%). The underlying rock consists of alluvial deposits. $\mathrm{Pl} \ldots+\mathrm{r}$ ots are developed through the soil down to more than $1.5 \mathrm{~m}$ in the case of whr. ${ }^{2}$ wilich resulted in SAWC between 170 and $230 \mathrm{~mm}$ [Garrigues et al., 2015].

The INRAE Avignon "Remote - Ising and flux site" records acquired between 2015 and 2017 on two successive $w_{1}$, ? $a_{\iota} r$ sps were used in this work. Daily ET was obtained from latent heat flux measurement ${ }^{-}$, vith the eddy-covariance method.

\subsubsection{The Fontaine de Vaucluse aquifer}

The Fontaine de Vaucluse spring is located South-East of France, about $40 \mathrm{~km}$ eastward of Avignon city (Figure 4). The Fontaine de Vaucluse is one of the biggest karst springs in the world [Chen et al., 2017]. It is the only outlet of a karstic system with an exceptional extension of $1162 \mathrm{~km}^{2}$ developed within a major relief of the Provence area [Carrière et al. 2016]. Geological and karstic features were mapped in Ollivier et al. [2020]. The MontVentoux summit (1912 $\mathrm{m}$ a.s.I.) at the West and the Lure summit at the East (1826 $\mathrm{m}$ a.s.I.), delineate a $62 \mathrm{~km}$ long mountain chain that defines the northern boundary of the 
watershed. The main part of the watershed corresponds to highland with a mean elevation of $850 \mathrm{~m}$. It is bounded on the East by the Durance river valley, on the South by the plains of Apt and on the West by the Rhone river valley. The landscape is mainly composed of natural area (84 \%), $15 \%$ is agricultural area and about $1 \%$ is urbanized. Natural areas include $52 \%$ of hardwood forests (holm oak, beeches, deciduous oak, chestnut...), $13 \%$ of coniferous forests (mountain pine, black pine, Corsican pine) and $7 \%$ of mixed forests (Figure 5). Scrublands, lawns and natural pasture, shrub and sparse vegetation cover $27 \%$ of the area. Rock outcrops are visible over less than $1 \%$ of the studied area. Soils are well developed over cultivated fields, and they are really stony and thin over $r$ ttural areas.

The absence of permanent rivers over the recharge area is a stro ig clue that most of surface water infiltrates and percolates to the groundwater. The, ofor 2 , it is possible to assume that most of the difference between rainfall and recharss 1 - due to ET. Because of the large variety of land cover and soil, a large spatial variablı.' of ET is expected over the studied area.

Fontaine de Vaucluse discharge has bf $\_n$ noritored since November 2003 by a gauging station installed in the river, $450 \mathrm{~m}$ dowı, tream of the spring. Water levels have been recorded every hour and converte ${ }_{\lambda}^{\prime}$ inc hourly discharge using the station's calibration curve [Ollivier, 2019]. In this stı..' w. use daily discharge data from November 2003 to August 2015. Over this period, disc'narge ranged from 2.8 to $82.5 \mathrm{~m}^{3} . \mathrm{s}^{-1}$, with an average of $13.2 \mathrm{~m}^{3} \cdot \mathrm{s}^{-1}$ and a median of $9.7 \cdot \mathrm{I}^{3} \cdot \mathrm{s}^{-1}$ (Appendix A).

A soil available water $\neg D^{-i^{+}}$y map of the top soil layer $\left(S A W C_{0}\right)$ was developed after 323 soil pits observations sprea $\downarrow$ Jver the watershed area. In Ollivier et al. [2020] an Artificial Neural Networks (ANN) was used to predict soil water holding capacity over the watershed area from environmental factors such as elevation, mountain side orientation, slope and vegetation amount The $S A W C_{0}$ map has a resolution of $1 \mathrm{~km}^{2}$ and $S A W C_{0}$ values range from $5 \mathrm{~mm}$ (limestone outcrop) to $240 \mathrm{~mm}$ (agricultural area). RMSE between the simulations and observations was $17 \mathrm{~mm}$ for natural areas and $13 \mathrm{~mm}$ for agricultural areas. 


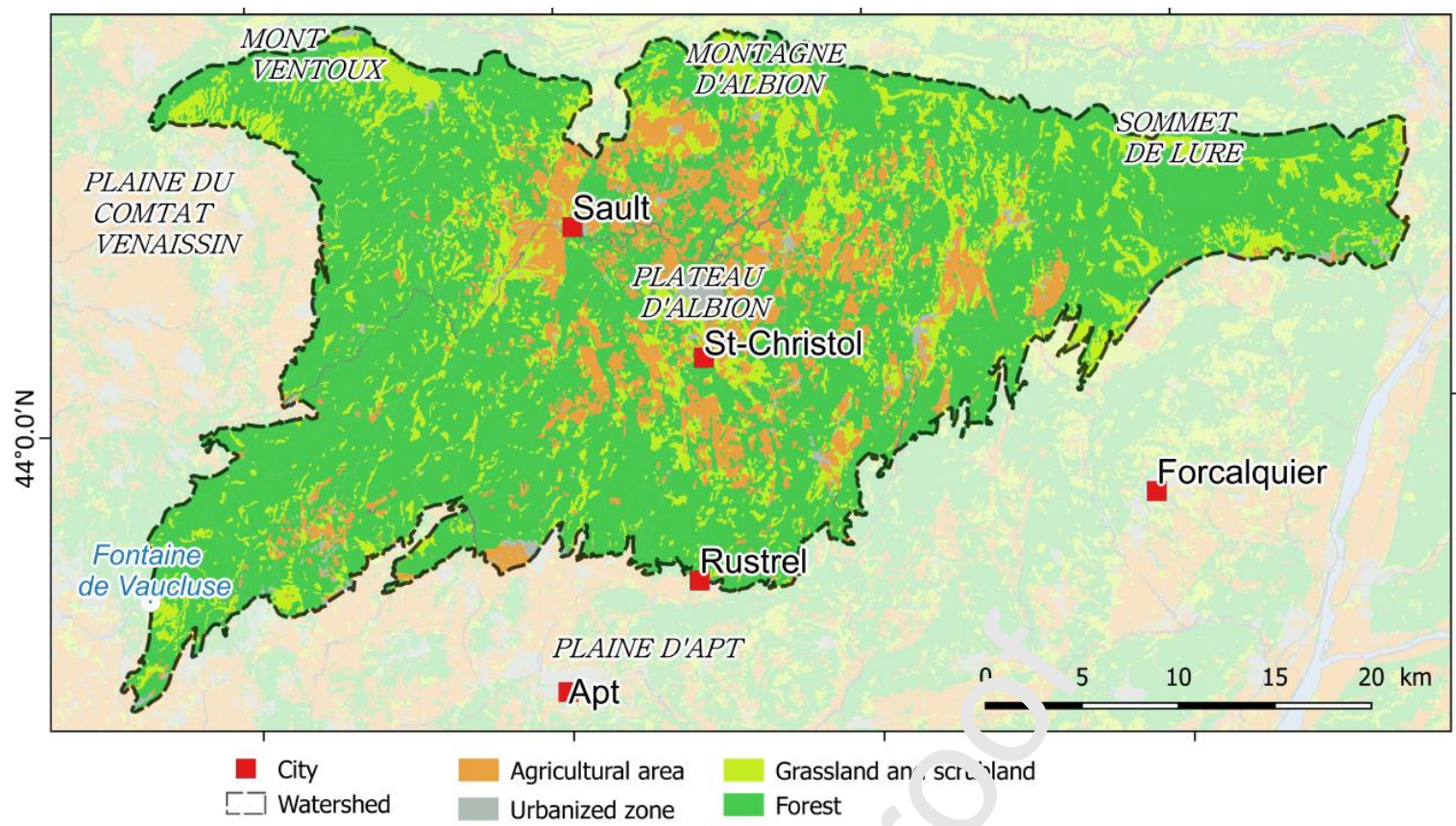

Figure 5: Land use and land cover of the watershe. of :ontaine de Vaucluse aquifer, after OCSOL-2014 data produced by the CRIGE-PACA ( :...,w.crige-paca.org)

\subsection{Climate data}

The climate data came from the CAFRAN product of METEO-FRANCE, the French meteorological service [Durand et i.., 2009, Quintana-Seguí et al., 2008]. SAFRAN is a weather data source available c'ver france on a grid of $8 \mathrm{~km}$ by $8 \mathrm{~km}$ at the daily scale starting in 1958. Precipitatior, गnci reference evapotranspiration data from SAFRAN are used, see details in Appendix D.

The four test sites are sı uated in the typical Mediterranean climate zone (Köppen-Geiger climate classification updated by Beck et al. [2020]). Winter is wet and cool, summer is hot and dry. Most of the precipitations occur during autumn and winter. Thus, climate is characterized by frequent summer droughts lasting at least for 2 months and regularly up to 4 months. Mean annual precipitation and temperatures of hydrological year from September 2000 to August 2016 are (Figure D-1): $981 \mathrm{~mm}$ and $10^{\circ} \mathrm{C}$ over Fontaine de Vaucluse watershed, $686 \mathrm{~mm}$ and $14^{\circ} \mathrm{C}$ in Font-Blanche, $807 \mathrm{~mm}$ and $14.5^{\circ} \mathrm{C}$ in Puechabon, $666 \mathrm{~mm}$ and $15^{\circ} \mathrm{C}$ in Avignon. Mean annual reference evapotranspiration is $1043 \mathrm{~mm}$ for Fontaine de Vaucluse watershed, $1184 \mathrm{~mm}$ in Font-Blanche, $1213 \mathrm{~mm}$ in Puechabon and $1248 \mathrm{~mm}$ in Avignon. The difference in climatic demands between these sites is mainly 
related to temperatures. It is interesting to note that years with lowest precipitation amounts are characterized by highest reference evapotranspiration values. The interannual variability of reference evapotranspiration is very low (maximum range around $200 \mathrm{~mm}$ ) compared to precipitation (maximum range around $700 \mathrm{~mm}$ ).

\subsection{Remote sensing data and fraction cover}

Remote sensing data were used to calculate the fraction of vegetation cover which was used as input into the ET model. The fraction of vegetation cover $\left(f_{\text {cover }}\right)$ represents the amount of land surface covered by vegetation.

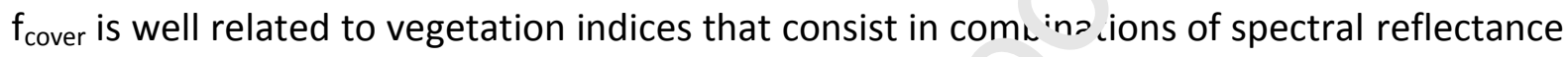
obtained from remote sensing images [e.g. Carlson an I $_{\text {, inl }} y$, 1997, Qi et al., 1994]. $f_{\text {cover }}$ can also be obtained from other remote sensing $\mathrm{p}$ ou 'cis and in particular derived using artificial neural network (ANN) models [Li et al., 2015, vinlo et al., 2016, Weiss et al., 2002].

We used the Enhanced Vegetation Index $\left(\Sigma_{i}\right.$; derived from the SAVI index, that was proposed before by Huete [1988], EV! is $r$ rovided as a standard product calculated from MODIS data on NASA web sites. It vas available at $1 \mathrm{~km}, 500 \mathrm{~m}$ and $250 \mathrm{~m}$ resolutions starting in February 2000 (Table 1) A.s CAVI, this index is less sensitive to soil background than the more classical NDVI [Bausc: and Neale, 1987, Choudhury et al., 1994, Huete et al., 2002, Huete, 1988] which $m_{a}$; be an important property when investigating the spatial variability of $f_{\text {cover, }}$ in karst arfas where soil is often poorly developed and where rocks outcrop areas can bc signifi iant. This is also important when monitoring the evolution of $f_{\text {cover }}$ with time when the oil brightness changes, for example because of rain. EVI, as well as SAVI, was also more linearly correlated to $f_{\text {cover }}$ than NDVI (Figure 6) [Carlson and Ripley, 1997, Choudhury et al., 1994, González-Dugo and Mateos, 2008, Olioso et al., 2019, Qi et al., 1994]. Several studies [e.g. Bausch, 1993, Choudhury et al., 1994, Helman et al., 2015] also demonstrated that vegetation indexes less sensitive to soil background, as EVI, presented higher correlations with crop coefficient for ET or for canopy transpiration than NDVI. The relation between $\mathrm{f}_{\text {cover }}$ and $\mathrm{EVI}$ was expressed as:

$$
\mathrm{f}_{\text {cover }}=\frac{E V I-E_{\mathrm{m}}}{\mathrm{EVI}_{\mathrm{x}}-\mathrm{EVI}_{\mathrm{m}}} \# 10
$$


where $\mathrm{EVI}_{\mathrm{m}}$ is the lower $\mathrm{EVI}$ value corresponding to bare soil area and $\mathrm{EVI}_{\mathrm{x}}$ the maximum $\mathrm{EVI}$ value usually corresponding to maximum vegetation cover $\left(f_{\text {cover }}=1\right)$. The values of parameters $\mathrm{EVI}_{\mathrm{m}}$ and $\mathrm{EVI}_{\mathrm{x}}$, specific to MODIS sensors, were set to 0.06 and 0.87 [as derived by Olioso et al., 2019]. Relations between EVI and $\mathrm{f}_{\text {cover }}$ were also proposed by $\mathrm{Mu}$ et al. [2007] with slightly different parameters.
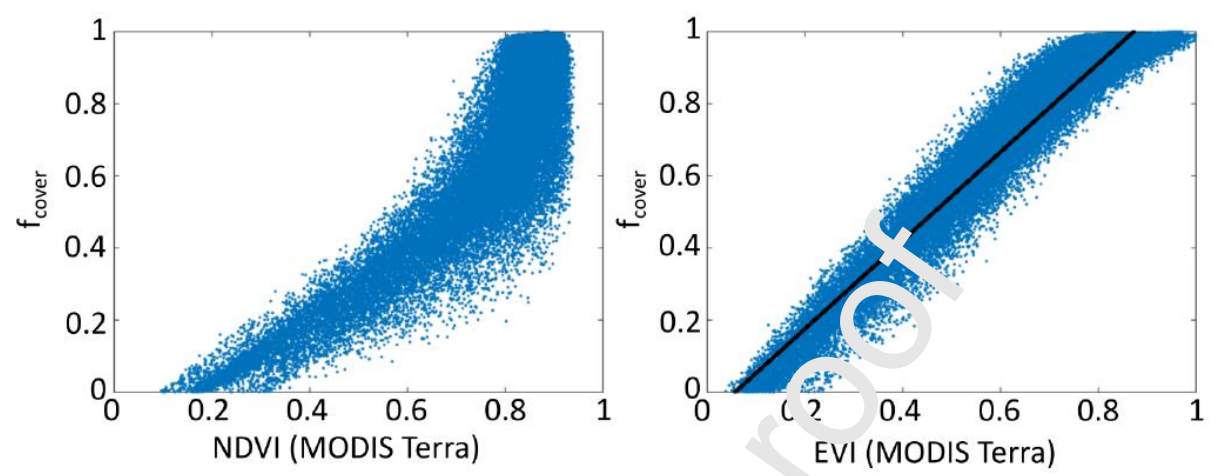

Figure 6: Relationship between fractional cover and vey station indices NDVI on the left and EVI on the right. Data were simulated for the 1 I IS sensor onboard Terra by Olioso et al. [2019] using the PROSAIL model.

We used EVI data with $250 \mathrm{~m}$ and $5 \mathrm{C} ? \mathrm{~m}$ resulution for the two local forest sites, Puechabon and Font-Blanche, and EVI data wit $n \perp \mathrm{km}$ resolution over the whole Fontaine de Vaucluse watershed (Table 1). $250 \mathrm{~m}$ anı bin $\mathrm{m}$ data were downloaded using the "point sample" utility from AppEEARS. They c rresponded to MODIS collection 5 and to the more recent collection 6. Collection 5 :- rot anymore available to download today. No significant differences were fou. $d$. et seen the two collections and the two spatial resolutions when used to feed SimpKcET $\triangle$ /ailable data correspond to a 16 days synthesis computed from the reflectance acquired every day by MODIS on board of the Terra satellite. The $1 \mathrm{~km}$ data were downloaded earlier from the REVERB NASA web site [2016] (this site is now shutdown but a similar tool is available at EARTHDATA [2019]) and corresponded to collection 5 (Table 1). $f_{\text {cover }}$ was calculated from EVI provided as 16 days synthesis and then interpolated at daily time step using a simple Savitzky-Golay filter (sgolayfilt function in Matlab software choosing a third order polynomial on 51 days moving time windows). This filter also provided a mean for smoothing the time series of $f_{\text {cover }}$ by reducing the impact of fast variations of EVI which 
may be related to "residual cloud contaminations, imperfect atmospheric corrections and directional corrections" [Kandasamy et al., 2013].

In the case of the Avignon agricultural site, MODIS data were not used as the field where ET measurements were performed was too small ( 2 ha). Instead, we used fraction covers which were computed from Sentinel-2 data with a $20 \mathrm{~m}$ resolution thanks to a neural network model. The neural network model was developed at EMMAH and is included in the ESA SNAP toolbox dedicated to the processing of Sentinel satellite images [Weiss and Baret, 2016]. This algorithm has also been integrated in an operational processing chain at University of Natural Resources and Life Sciences of Vienna (A stria) by Vuolo et al. [2016]. For the period we considered, only images from Sentinel-2 i we re available every 10 days. However, as Avignon was in view of the satellite fror' th $\mathrm{s}$ different tracks, data were provided more frequently. Overall, 88 cloud free imasss vere obtained over the simulation period (24 months). As the evolution of Sentinel- $2 f_{\text {sov }}$ - were quite smooth, a simple linear interpolation was used to provide daily values $\mathrm{c} \mathrm{f}_{-\mathrm{or}} \mathrm{r}$.

Table 1: Remote sensing data product sei to compute $f_{\text {cover }}$ of Puechabon, Font-Blanche, Avignon and Fontaine de Vaucluse sites.

\begin{tabular}{|c|c|c|c|c|}
\hline Site & Sensor & ? asolution & Method & Product name \\
\hline Puechabon & MODIS (Ter $\ni)$ & $\begin{array}{c}250 \mathrm{~m} \text { and } \\
500 \mathrm{~m}\end{array}$ & Linear EVI & $\begin{array}{l}\text { MOD13Q1.006 } \\
\text { MOD13Q1.005 }\end{array}$ \\
\hline Font-Blanche & MODIS (7e rra) & $\begin{array}{c}250 \mathrm{~m} \text { and } \\
500 \mathrm{~m}\end{array}$ & Linear EVI & $\begin{array}{l}\text { MOD13Q1.006 } \\
\text { MOD13Q1.005 }\end{array}$ \\
\hline Avignon & Sf $n t t_{1}$ el-2 & $20 \mathrm{~m}$ & Neural Net & S2_FCOVER \\
\hline $\begin{array}{c}\text { Fontaine de } \\
\text { Vaucluse } \\
\text { Watershed }\end{array}$ & MOD S (Terra) & $1000 \mathrm{~m}$ & Linear EVI & $\begin{array}{c}\text { MOD13Q1.005 } \\
\text { tile h18v04 }\end{array}$ \\
\hline
\end{tabular}

\subsection{SimpKcET implementation}

The SimpKcET model was applied using parameters obtained either from the information already available from previous studies over each site or from standard values. In most cases, there was only little information available to set parameter values, so that we used uniform values whatever the soil and the vegetation types. Distributed information was only available for available water capacity of top soil layer $\left(\mathrm{SAWC}_{0}\right)$ over the Fontaine de Vaucluse watershed [Ollivier et al., 2020]. The maximum value of the canopy transpiration coefficient 
$\left(k_{T x}\right)$ was set to a uniform value of 0.9 whatever the type of canopy. This value was lower than values usually used for irrigated crops as specified in the FAO56 methods [Allen et al., 1998] that generally ranged between 0.95 and 1.15 (but in some cases up to 1.5). Actually, a lower value was set as the potential ET from SAFRAN data were higher than the FAO56 reference evapotranspiration. A uniform value was applied as no information existed on coefficient variations for the types of vegetation present in our area. No adjustment for vegetation height, albedo, stomata characteristics, wind speed or air moisture was done. Concerning soil parameters, the threshold in the water stress coefficient $k_{s}$ was considered equal to $2 / 3$ in all situations. Coefficient $b$ in the calculation of $k_{i_{i j}}$ was set to 2.5 .

Over the whole Fontaine de Vaucluse watershed, the soil w ter iolding capacity SAWC was obtained as a first guess from the $\mathrm{SAWC}_{0}$ map described ?arlı 2 [Ollivier, 2019, Ollivier et al.

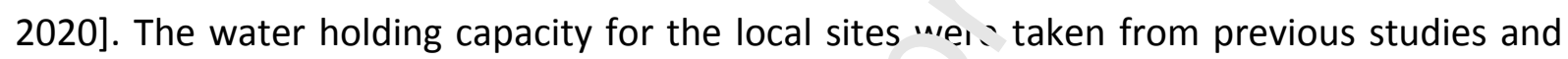
set to $120 \mathrm{~mm}, 150 \mathrm{~mm}$ and $225 \mathrm{~mm}$ for Puechat -. [Allard et al., 2008], Font-Blanche [Marie and Simioni, 2014] and Avignon [Garrig er ct al., 2015], respectively. For Puechabon and Font-Blanche, these estimations wer- cig. ificantly larger than the estimation of SAWC derived from soil pits which ranged from 0 to $70 \mathrm{~mm}$. Indeed, soil pits measurements are limited by the amount of rocks and the nossibility to dig the pits. Tree roots are penetrating through rocks fractures and are abie tc access underground horizons that are deeper than the one explored through soil pIL: [Alıard et al., 2008, Rambal, 1982]. This behaviour may be exacerbated in dry periods as : hown by Carrière et al. [2020a, 2020b] through the analysis of transpired water origir usihis water isotopes concentration. This may have a large implication on the derı: atıun of the SAWC map over the Fontaine de Vaucluse watershed. Thus, actual available water capacity should be larger than estimated by our previous analysis which only considered soil pits depth. We revised our SAWC map by introducing an additional water quantity termed $S A W C_{\text {add }}$ that was directly added to the original SAWC values. Roughly, this can be seen as splitting the reservoir of available water in two parts, $\mathrm{SAWC}_{0}$ which corresponds to the layer accessible to soil pits (and which is equivalent to the original SAWC values as defined by Ollivier et al. [2020]) and SAWC $C_{\text {add }}$ which corresponds to a subsoil layer not accessible to soil pits so that: $S A W C=S A W C_{0}+S A W C_{a d d}$. As no information was available on the spatial variations of this additional subsoil term, a uniform value was used over all the natural and forested areas. Final value of SAWC add was obtained 
through the calibration of the KaRaMel - SimpKcET model as presented in the next section. No additional value $S A W C_{\text {add }}$ was introduced for the agricultural areas, as soil pits were expected to cover the full root zone.

In Puechabon and Font-Blanche, an evaporation reduction coefficient (1- $f_{\text {rocks }}$ ) of 0.3 and 0.5 was introduced as a very large portion of the soil surface was covered by rocks. These values were derived from the density of rocks and coarse elements given in Allard et al. [2008] and Marie and Simioni [2014]. No reduction was introduced for the crop field in Avignon. No Information on the spatial variations of $f_{\text {rocks }}$ was available over the Fontaine de Vaucluse watershed, so that a uniform value was applied over naturc. and forested areas. As for $\mathrm{SAWC}_{\text {add }}$ this value was obtained through the calibration of the raRaMel - SimpKcET model as presented in the next section.

\subsection{Model calibration and evaluation}

\subsubsection{Calibration of KaRaMel}

The original KaRaMel model was implem en ed sver the Fontaine de Vaucluse watershed in Ollivier et al. [2020]. Here, KaRaMel was $\mathrm{n}$. ndified to incorporate the SimpKcET model and then tested against Fontaine de $V^{-} \cdot c_{c}$ 'se discharge and against the original version of KaRaMel with the bucket ET mod -1 ( : _ure 1). KaRaMel is used to simulate the karst aquifer discharge depending on the ET mu tel. Delaigue et al. [2018] compared the performance of five hydrological model calibrction algorithms implemented in $\mathrm{R}$ programming language. Their results show that or s simple lumped model calibration, the algorithms differ in the time allocated to find the optimum, but they all converge towards the same optimum. In the present study both a particle swarm optimization [Zambrano-Bigiarini and Rojas, 2013] and differential evolution optimisation [Ardia et al., 2011] algorithms were applied. Both algorithms converged to the same optimum for the initial version of KaRaMel, with five parameters. However, the current version of KaRaMel, including SimpKcET, required the calibration of two additional parameters, which implies a significant additional time of calculation for the particle swarm optimisation algorithm and difficulties to converge. Thus, the calibration step was performed with the differential evolution optimisation, and used a single objective function, the Kling Gupta efficiency (KGE, described in Appendix A) after Gupta et al. [2009]. KGE reached 1 for the best adjustments. Calibration was performed 
against daily spring discharge of the aquifer from September 2006 to September 2009 (three hydrological years, see Appendix A). The set of parameters providing the best performance with respect to the KGE objective function was retained (it is presented in Appendix A).

\subsubsection{Evaluation of evapotranspiration simulations}

ET simulated with SimpKcET, on local test sites in Avignon, Puechabon and Font-Blanche were evaluated using the root mean square error (RMSE) and the mean error (bias) against ET measurements (RMSE and bias evaluation functions are given in Appendix A). They were also compared to the ET simulated with the bucket model.

Particular emphasis is placed on the overall form of evapotran, iration. In particular, the influence of the two parameters $S A W C_{\text {add }}$ and $f_{\text {rocks }}$ on evapnt $t_{1}=n$,piration simulations.

For the Fontaine de Vaucluse test site, the ET simulatea vith the bucket model is symbolized by ETbu and the ET simulated with SimpKcET by E - sim . The simulated aquifer discharge depending on ET, is compared to discharge obse . tions using KGE, RMSE and bias.

\subsubsection{Cross wavelet analysis}

Cross wavelet analysis can be used to prov te a representation of the time-scale distribution of correlation between environmental w vriables [Labat et al., 2005, Labat, 2010, Sang, 2013, Charlier et al. 2015]. In this study or is', wavelet analysis, including cross wavelet spectrum and wavelet coherence, enak'es the localization in time-scale space of high degree of relationships between simulaı $d$ recharge and observed discharge signals. The assumption is that the closer the sim 1 la: on of the recharge is to reality, the more this signal will be correlated with the obst ved discharge of the aquifer.

The reader is referred to Kumar and Foufoula-Georgiou [1997], Labat et al. [2000a, b] and Labat [2005] for mathematical details of cross wavelet analysis. Morlet wavelet was chosen as it is fairly well localized in both time and frequency space [Torrence and Compo, 1998], giving good results for the analysis of hydrogeological time series for karst aquifers [Charlier et al., 2015]. Cross wavelet spectrum (XWT) estimates the linear relationship between two signals, revealing the area in the time-scale space with a high common power value. The wavelet coherence (WTC) is a qualitative estimator of the intensity of the correlation of the 
two series in the time-scale space. The wavelets analysis was performed using the WaveletComp package on R programming language [Rosch and Schmidbauer, 2019].

\section{Results}

\subsection{ET model performances at local scale}

The results of the evaluation of the ET model SimpKcET over the three local sites are presented in Figure 7 and Table 2. Simulated ET are also compared to results obtained from the bucket model that was originally used within KaRaMel.

ET is characterized by a seasonal dynamic in relation to anilu...e energy (in particular solar radiation), which particularly drives the climatic dema. Id $; 0$, and to vegetation amount and soil water availability which may involve limita ion of ET in comparison to ETo. ETo is high during spring and summer. For the three sites, actual ET is low in winter, then increases in spring before decreasing rapidly in early sim. ne. The highest recorded ET from the two forested sites occurs in early summer, vhe I water is still available and vegetation activity and climatic demand are high. The highest LT for the crop site occurs in spring when cereal crops reach their maximum vegetativ acvelopment. During summer, despite high climatic demand, ET decreases for both $\ldots$, iurested sites and the cultivated field. ET from forest areas is limited by the soil's $u$ ter , eserve, which dries up in summer, while crop field ET is limited by plant senesceri-a a d then harvesting. After harvest the soil is kept bare or covered by stubbles In the three sites ET remains low until the first rainy event in early autumn. Then, as water is no longer the main limiting factor, ET dynamics follow the dynamics of climatic demand, which decreases until winter. We can also notice that in winter, ET of the two forest sites are lower than ETo, even with non-limited water availability. This result may be related to the level of vegetation cover, which never exceeded 0.5 and which limits transpiration, and to the presence of coarse elements at the soil surface, which limits evaporation.

Table 2: parameters and results for the SimpKcET model for the three test sites with evapotranspiration measurements. The RMSE and bias indices (described in Appendix A) are 
evaluated at daily and monthly time scales against evapotranspiration measurements performed using micrometeorological tower stations.

\begin{tabular}{|c|c|c|c|c|c|c|c|c|}
\hline & \multirow{2}{*}{\multicolumn{4}{|c|}{ Model parameters }} & \multicolumn{4}{|c|}{ Model performances } \\
\hline & & & & & \multicolumn{2}{|c|}{ Daily scale $\left[\mathrm{mm} \cdot \mathrm{d}^{-1}\right]$} & \multicolumn{2}{|c|}{$\begin{array}{l}\text { Monthly scale } \\
{\left[\mathrm{mm} . \mathrm{month}^{-1}\right]}\end{array}$} \\
\hline & $\begin{array}{l}\text { SAWC } \\
{[\mathrm{mm}]}\end{array}$ & $\mathrm{k}_{\mathrm{TX}}$ & $f_{\text {rocks }}$ & $b$ & RMSE & bias & RMSE & bias \\
\hline Font-Blanche & 150 & 0.9 & 0.5 & 2.5 & 0.49 & 0.14 & 8.63 & 4.36 \\
\hline Puechabon & 120 & 0.9 & 0.8 & 2.5 & 0.50 & -0.04 & 10.6 & -1.85 \\
\hline Avignon & 200 & 0.9 & 0 & 2.5 & 0.51 & 0.13 & - & - \\
\hline
\end{tabular}

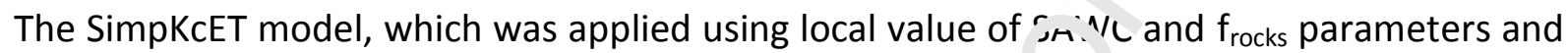
standard values for each other parameters, was able to $r=p$ : ouuce ET dynamic with a good accuracy. It provided performances with RMSE close tc $0.5 \mathrm{Inm} . \mathrm{d}^{-1}$ and bias lower than 0.15 $\mathrm{mm} \cdot \mathrm{d}^{-1}$ (Table 2). These performances are good, , pirticular with no calibration of the model and the use of generic values for parameters such as $k_{T X}$ which may be a very sensitive parameter of SimpKcET. Thus, it is ex =-ted that after calibration, performances might be improved further. Howeve: $v$ e should notice that the daily ET for these ecosystems is usually low, ranging frc $\mathrm{m} 0$ to $\mathrm{mm} \cdot \mathrm{d}^{-1}$, with an annual average of $1.2 \mathrm{~mm} \cdot \mathrm{d}^{-1}$. Periods with the largest difference, $r_{c}+$ ween the simulated ET and the measurements are most probably linked to the diff sre.res between local rainfall and rainfall inputs from the SAFRAN reanalysis (at $8 \mathrm{~km}$ res lution). See in particular, the early drop in the simulated ET at the beginning of summer ? $00 y$ in Puechabon. 
a) Font-Blanche
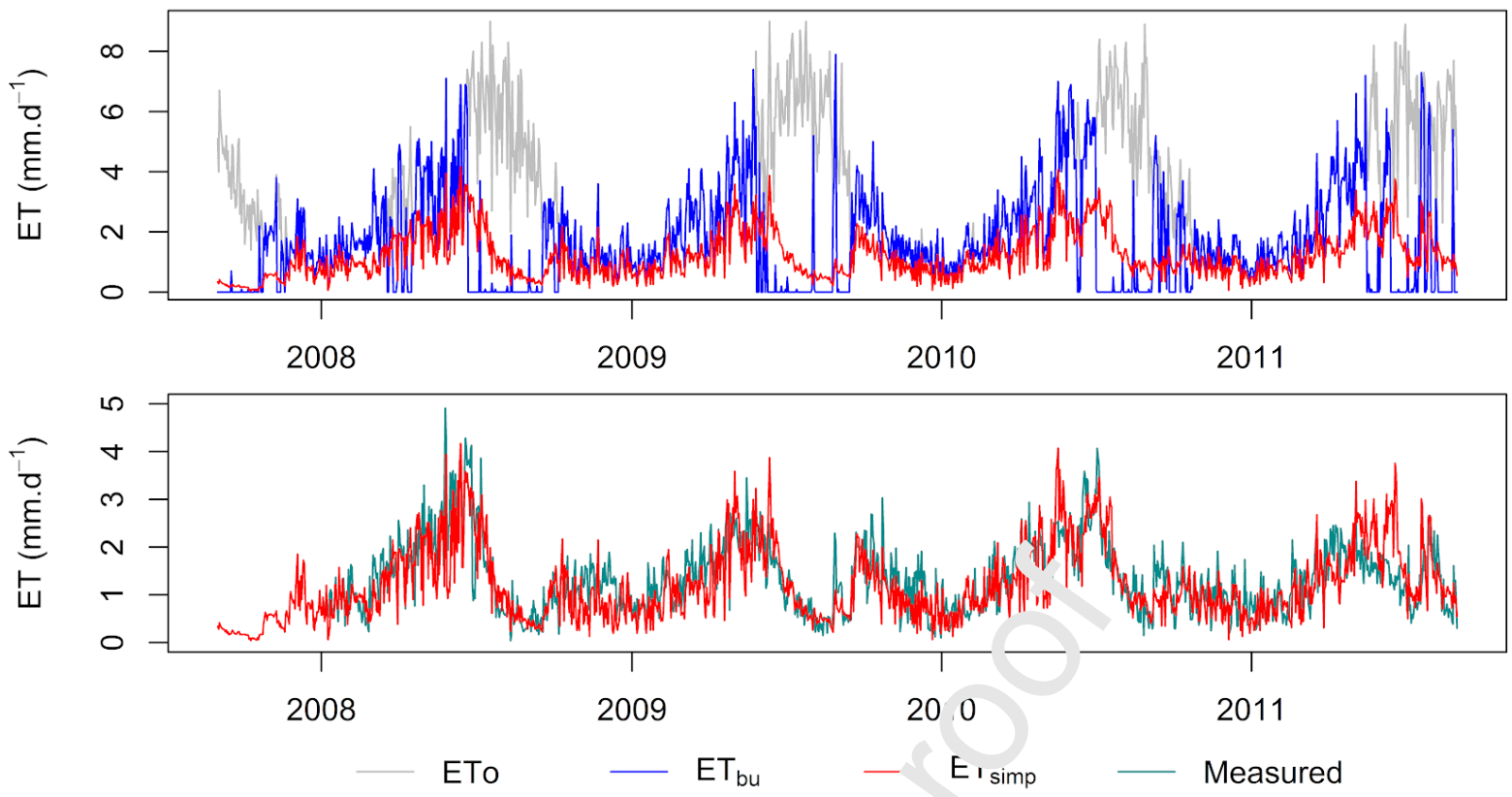

b) Pueci. abr $n$
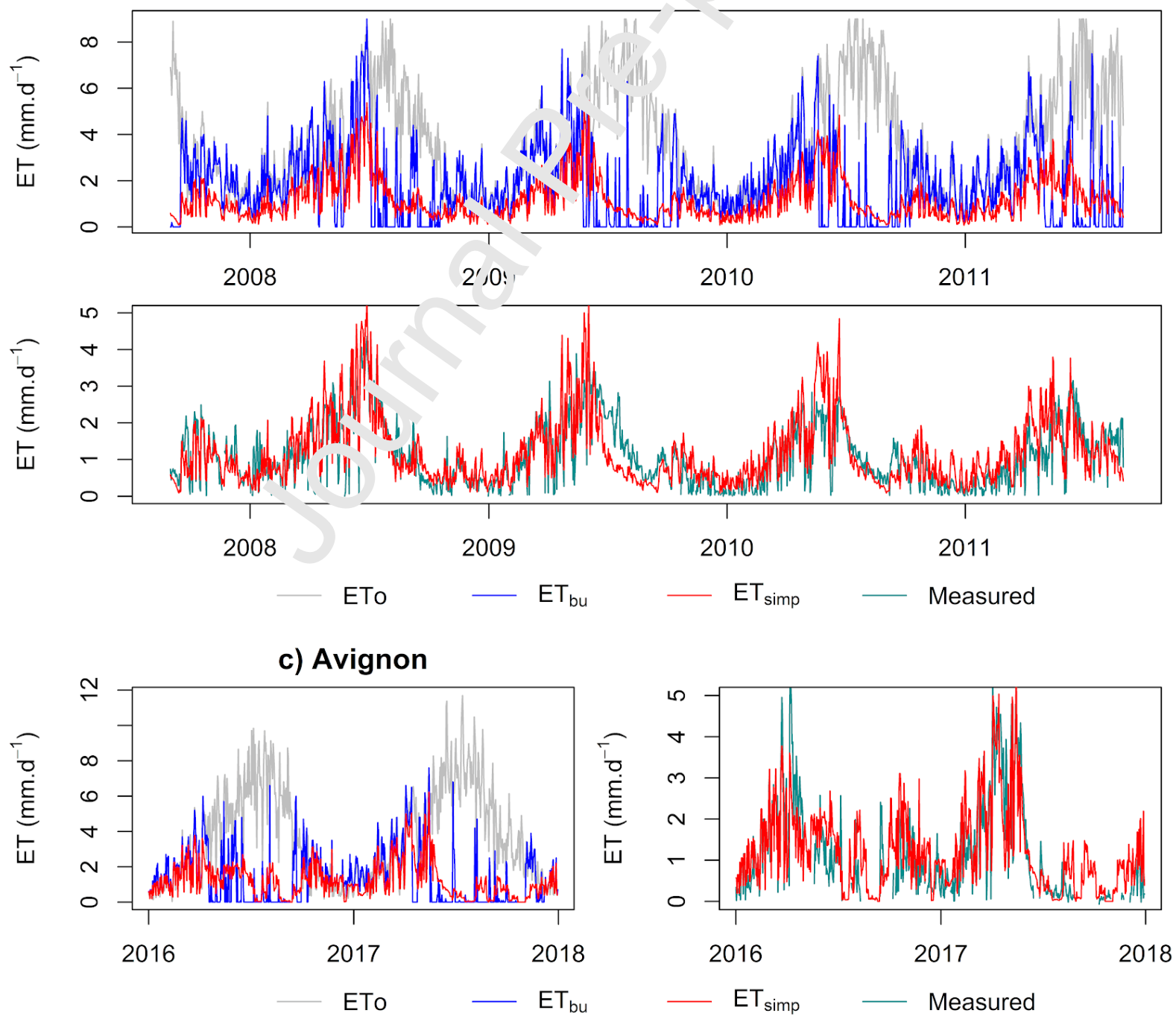

Page 26 / 67 
Figure 7: Reference evapotranspiration (ETo, grey lines), simulated evapotranspiration with the bucket model (ETbu, blue lines) and SimpKcET (ETsimp, red lines) and measured evapotranspiration (Measured, green lines) from September 2007 to August 2011 for FontBlanche and Puechabon sites and from January 2016 to December 2017 in Avignon.

The bucket model poorly reproduced the dynamics of ET, as simulated ETbu is equal to ETo in winter and at the beginning of spring, then decreases down to zero as soon as the soil reservoir is empty. Rainy events refill the soil reservoir and ETbu may then re-increase up to ETo level (or at lower level if precipitation amount is lower than ETo). The simulated ET is nil most of the summer season, with occasional ET peaks after recipitation events. Periods with no ET occur early, when spring is dry as during 2007 ar 12() 8 . ETbu retrieves the level of ETo in autumn after the first period of heavy rain.

\subsection{Model simulations over the Fontaine de $V$. ucl ise watershed}

\subsubsection{Influence of SAWCadd and frocks on ET s' $m$ l lated at watershed scale}

The two parameters $S A W C_{\text {add }}$ and $f_{\text {rocks }}$ r. Ia) have a large impact on the simulation of ET at the watershed scale and thus an impact 0 , the recharge and the flow at the outlet of the karst system. They were calibrated to zether with KaRaMel parameters by comparing simulated outflow to measuremr ats : . Appendix A, giving values of $194 \mathrm{~mm}$ for $\mathrm{SAWC}_{\text {add }}$ and 0.26 for $f_{\text {rocks. }}$ In order to llus 'rate their impact on the simulated ET at the watershed scale, simulations with SAWC $C_{\text {adı }}$ values between 0 and $300 \mathrm{~mm}$ and $f_{\text {rocks }}$ values between 0 and $100 \%$ are presenter in 1 igure 8 .

The value of $\mathrm{SAWC}_{\mathrm{add}} \mathrm{har}$ a great influence on the simulations during the dry period (Figure 8-a). During that period, the smaller the water retention capacity of the surface and the subsurface, the earlier in the season evapotranspiration is limited. Carrière et al. [2020a, b] show that the water stored in the karst unsaturated zone can have a critical role in the ability of plants to resist water stress periods. SAWC $\mathrm{Cdd}_{\mathrm{a}}$ has no influence on evapotranspiration during the rest of the year, as water availability is higher because of precipitations. The reduction of evaporation by the presence of pebbles at the soil surface ( $f_{\text {rocks }}$ ) has an influence on the evapotranspiration of the watershed throughout the year and 
in particular for the wet periods (Figure 8-b). Its influence is minimal during dry periods, as during these periods the transpiration is the main component of the evapotranspiration flux

a) SAWC $_{\text {add }}(\mathrm{mm})$

$\begin{array}{lllll}0 & 75 & 150 & 225 & 300\end{array}$

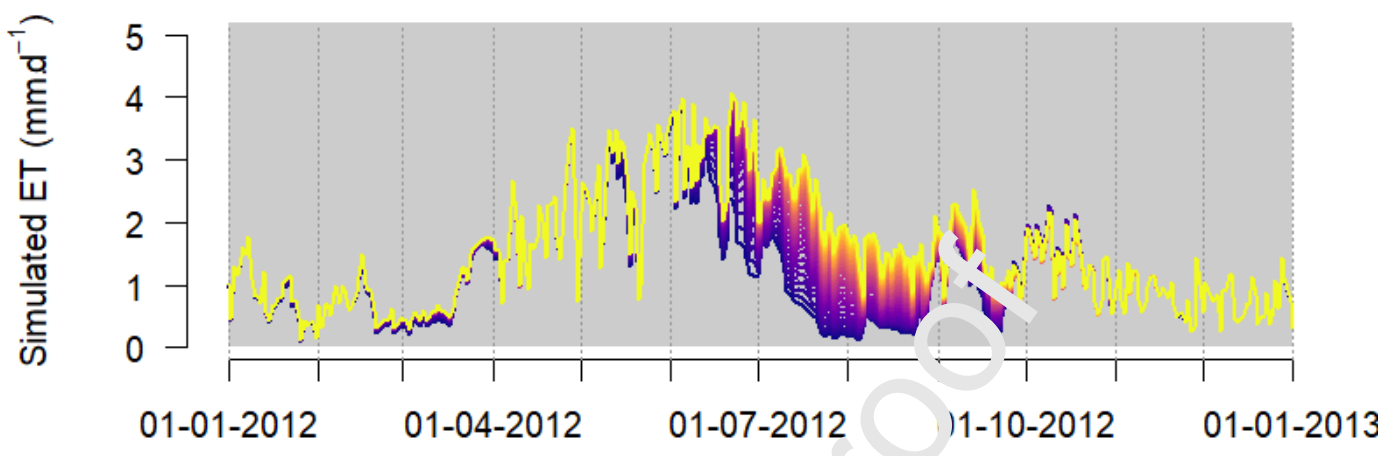

b) $\mathrm{f}_{\text {roci. }}(\%)$
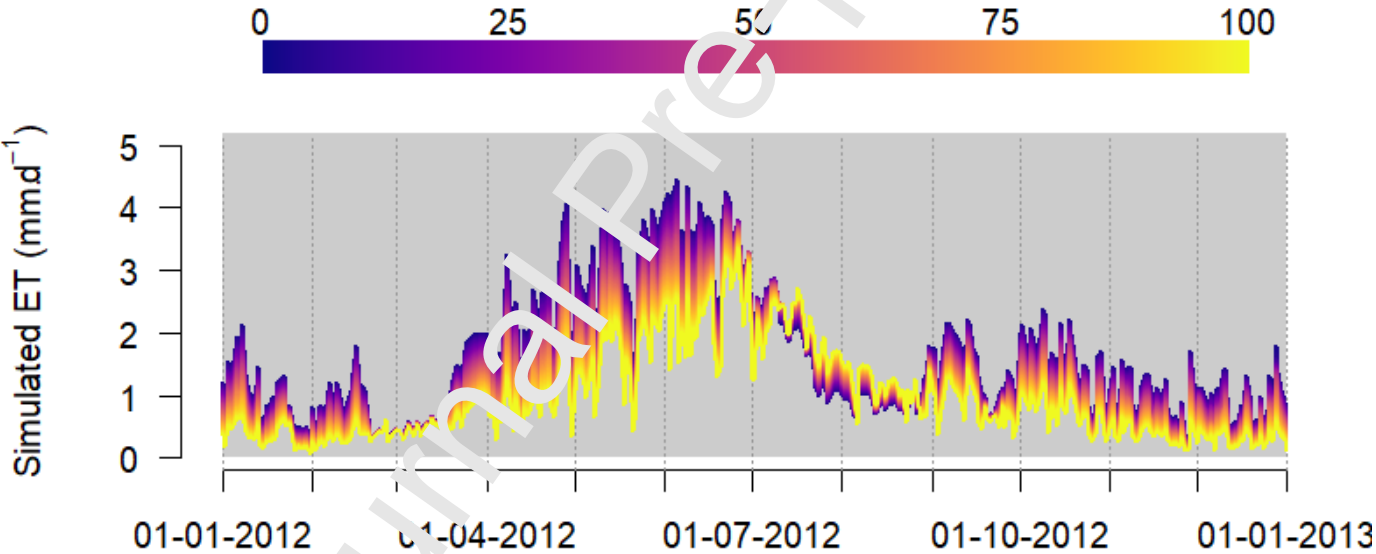

Figure 8: At the scale of the Fontaine de Vaucluse watershed, the ET simulation is sensitive to the values of the parameters: a) $S A W C_{\text {add }}$ and b) $f_{\text {rocks. }}$

\subsubsection{ET simulation over the Fontaine de Vaucluse watershed}

The daily reference evapotranspiration (ETo) and daily evapotranspiration simulated with SimpKcET (ETsimp) and the bucket model (ETbu) at the scale of the Fontaine de Vaucluse watershed are presented in Figure 9. Over the validation period from September 2009 to May 2015, ETo ranged from 0.03 to $8.7 \mathrm{~mm} \cdot \mathrm{d}^{-1}$, ETsimp from 0.02 to $4.8 \mathrm{~mm} \cdot \mathrm{d}^{-1}$ and ETbu from 0 to $7.5 \mathrm{~mm} \cdot \mathrm{d}^{-1}$. The general ET dynamics were quite similar from one year to another and were very coherent with the dynamics obtained at the local sites. The climatic demand presented a very marked seasonal cycle, increasing from winter to summer and decreasing 
from summer to winter. Simulated ET were lower than ETo during spring and summer indicating the impact of the depletion of available water. Similarly, to local forest sites, ETsimp is always lower than ETo in winter, because of the reduction of soil evaporation imposed by the $f_{\text {rocks }}$ parameter which was set to 0.26 and the reduction of transpiration imposed by low values of $f_{\text {cover }}$ in winter (in particular for deciduous forest and crops).

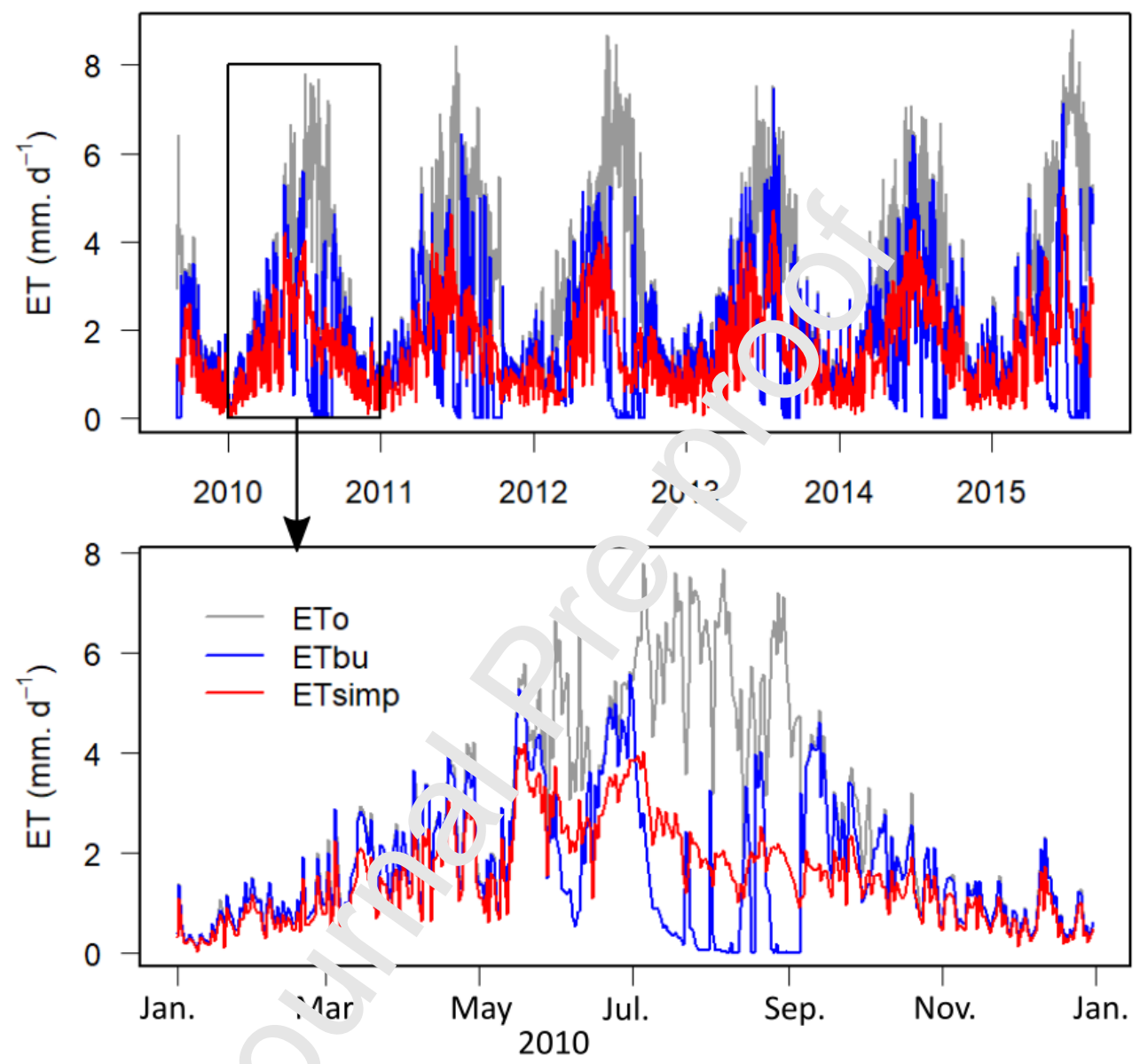

Figure 9: Reference evapı transpiration (ETo), evapotranspiration simulated with the bucket model (ETbu) and evapotranspiration simulated with SimpKcET (ETsimp) for watershed of Fontaine de Vaucluse aquifer.

At watershed scale, differences between the two ET models were similar to those observed at local scale. The ETbu simulated by the bucket model sustained the climatic demand as long as water was available and stopped when the soil reservoir was empty, while SimpKcET exhibited slower decreases in ET without reaching zero. The bucket model reached the nil ET level in summer, but later than for the simulations at local sites (and never in spring). This is explained by lower ETo, higher rain and by the spatial distribution of ET responses related to 
spatial variations in SAWC and $f_{\text {cover }}$ which combine together for generating ET at the watershed scale.

Examples of ET simulated for different types of land cover are given in Figure 10, together with the evolutions of $f_{\text {cover, }} k_{T}, k_{E}$ and $k_{S}$ for year 2010. Forests of deciduous oaks, evergreen oaks, pines and beeches and an agricultural area are presented. We selected model meshes areas with values of $\mathrm{SAWC}_{0}$ close to $110 \mathrm{~mm}$. Aerial photographs from the Region ProvenceAlpes-Côte-d'Azur survey of the selected areas are presented in Appendix $C$ showing the diversity in vegetation conditions. The activity of beech forests and deciduous oak forests had strong seasonal dynamics with a maximum fraction cove 'ip to 0.6 for deciduous oak and 0.8 for beech at the end of spring and between 0 and $0 .:$ in 1 inter. Evergreen oak forest and pine forest had lower seasonal changes with fractio 1 co ers between 0.2 and 0.4 . The agricultural area had also a low fraction cover (be+in/tin 0 and 0.4 ) with a multimodal seasonal dynamic related to the mixture of various $t_{y},-s$ of crops with different vegetation cycles (mostly wheat, lavender and grassland) V.ren considering simulated ET, the global dynamics were very similar for the differ...t $\mathrm{k}$ nd cover, with some slight variations related to the differences in $f_{\text {cover }}$ and the dynamı of water stress related to SAWC.

The examination of $k_{T}, k_{E}$ and $k_{S}$ pre . te insights in the regulation of evapotranspiration for each vegetation type (Figure 10', ' So.'. evaporation is strong during autumn and winter, it decreases in spring to reach "ᄏlue close to zero in summer, in relation to higher climatic demand and lower occurrence is rainfall. The highest vegetation fraction covers (e.g. for the beech forest) also tend $o$ li, nit soil evaporation. Transpiration strongly depends on $f_{\text {cover }}$ in winter and autumn and $\mathrm{o}$, the deficit in available water by mid-spring and summer (see $k_{s}$ ). 


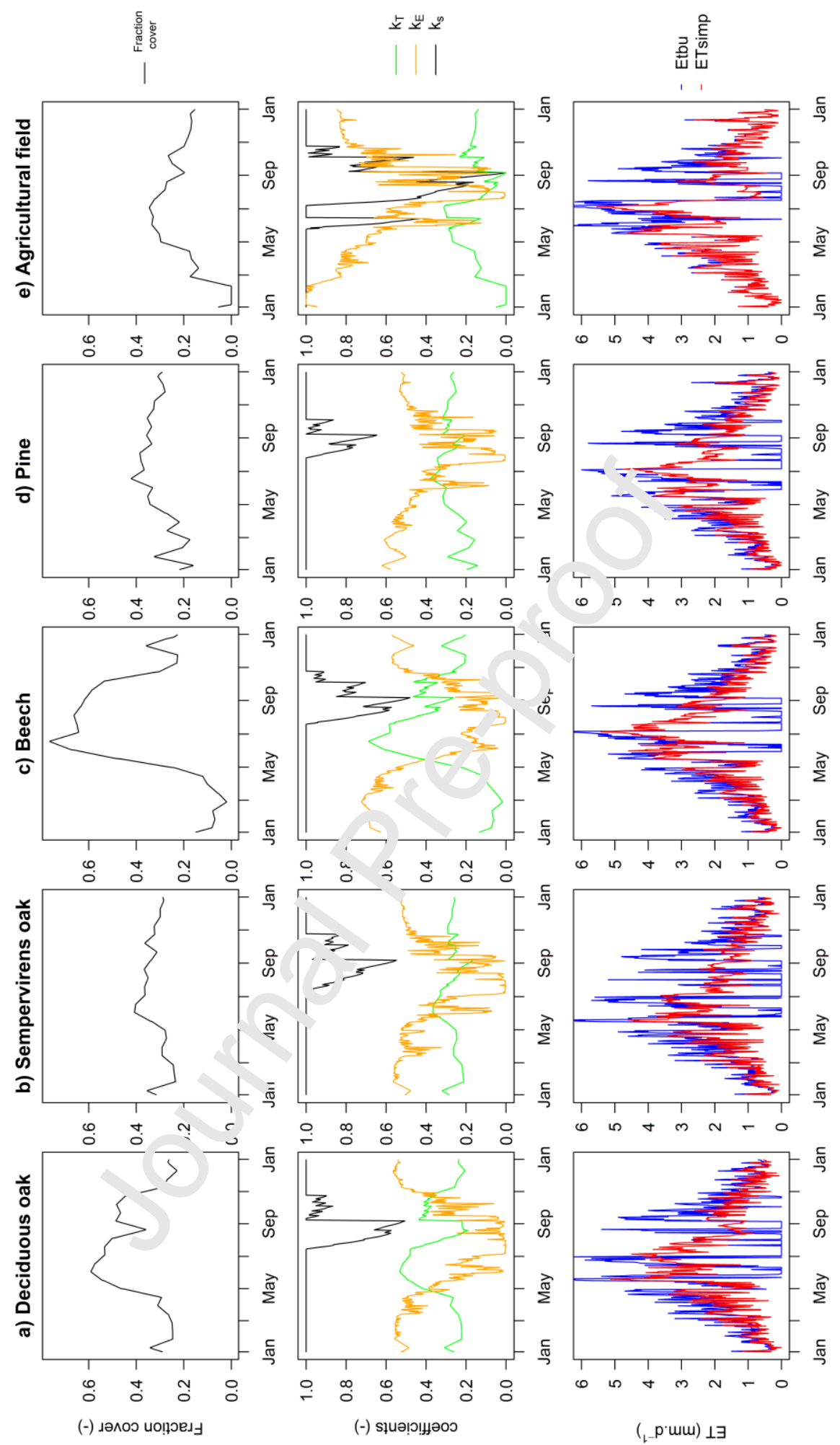

Figure 10: The vegetation fraction cover $\left(f_{\text {cover }}\right)$, the soil evaporation coefficient $\left(k_{E}\right)$, the water stress coefficient $\left(k_{S}\right)$ and the canopy transpiration coefficient $\left(k_{T}\right)$ depending on the vegetation of area of Fontaine de Vaucluse watershed: a) Deciduous oak, b) Evergreen oak, c) Beech, d) Pine and e) Agricultural field during 2010. 
Spatial variations of ET calculated with SimpKcET are presented in Figure 11 at monthly time scale for year 2010. The spatial pattern of ET is strongly controlled by the pattern of precipitation. The 8 by $8 \mathrm{~km}$ grid of the SAFRAN meteorological dataset is clearly visible, as well as a larger scale pattern which is related to the definition of "isoclimatic" zones (SYMPOSIUM zones) for distributing meteorological information the scale of the SAFRAN grid by METEO-FRANCE (for more details see the appendix C in Ollivier 2019). This larger scale pattern is clearly visible in July, the values are contrasted between the East and West of the watershed, in reason of one strong precipitation event mainly affecting the East part of the watershed at mid-June (West: $\sim 50 \mathrm{~mm}$; East $\sim 150 \mathrm{~mm}$ ).

At a finer scale than SAFRAN grid, the spatial pattern of eve yotr anspiration is controlled by the pattern of $S A W C_{0}$ and $f_{\text {cover }}$. The role of the soil is strong er where $S A W C_{0}$ is low. Areas with low $\mathrm{SAWC}_{0}$ are also flat areas with a high densit:! oi karst features (dolines and faults) which promote recharge and reduce the availability - . water for evapotranspiration (see geological map in Ollivier et al. [2020]). The pacterns of meteorological data and SAWC explain most of the spatial variability of the monthly evaporation from October to April. From May to September, the spatial varia lity of the evapotranspiration is also impacted by the vegetation activity. 

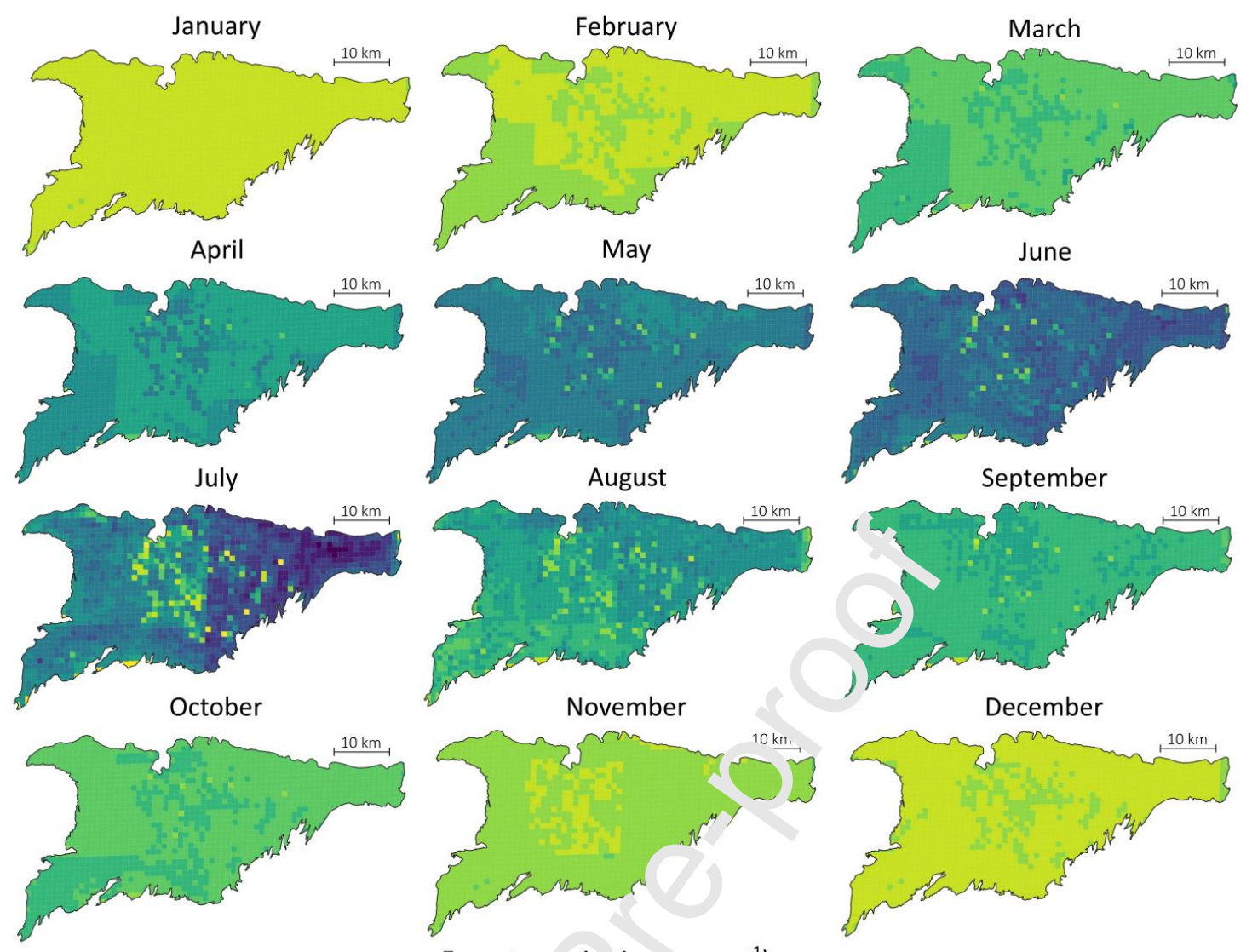

Evapotra' spir tion, $\mathrm{mm} \cdot \mathrm{m}^{-1}$ )

$\begin{array}{lllllll}10 & 30 & -n & 70 & 90 & 110 & 130\end{array}$

$10 \quad 30 \quad-170 \quad 90 \quad 110130$

Figure 11: Spatial distribution c' mu.thly evapotranspiration over Fontaine de Vaucluse watershed during 2010.

\subsubsection{Evaluation of the kar + $v$ esponse (discharge)}

Both versions of the mi $\mathrm{Nr}_{\text {, }}$ (KaRaMel + bucket model and KaRaMel + SimpKcET) were calibrated against flow r,easured at the Fontaine de Vaucluse spring over the 2006-2009 period (see Appendix A). The models were evaluated over the 2009-2015 period. According to the statistical analysis of daily flow, daily flows above the $3 r d$ quantile ( $23 \mathrm{~m}^{3} \cdot \mathrm{s}^{-1}$ ) correspond to high water periods, while flows below the 1st quantile $\left(<8 \mathrm{~m}^{3} \cdot \mathrm{s}^{-1}\right)$ correspond to low water periods. The introduction of a better representation of the ET induces an improvement of the simulation of the aquifer flows, as summarized by the increase of the KGE from 0.92 to 0.95 . In addition, the average error between the simulation of the aquifer flows and the observation decreases from 4.6 to $3.4 \mathrm{~m}^{3} . \mathrm{s}^{-1}$. These reductions concerned the high water and low water, since the mean error decreased by about $25 \%$ and $50 \%$ 
respectively (Table 3). This is illustrated, for example, by a better estimation of the flood flow observed in winter 2011 and spring 2012 (Figure 12).

Table 3: The KaRaMel's performance over the validation period (2009-2015), according to the used evapotranspiration model.

\begin{tabular}{|c|c|c|c|c|c|c|}
\cline { 2 - 7 } \multicolumn{1}{c|}{} & \multicolumn{3}{c|}{\begin{tabular}{c} 
All data from 2009 to \\
\multicolumn{1}{c|}{2015}
\end{tabular}} & $\begin{array}{c}\text { Low flows } \\
\leq 8 \mathrm{~m}^{3} . \mathrm{s}^{-1}\end{array}$ & $\begin{array}{c}\text { Int. flows } \\
{[8,23] \mathrm{m}^{3} . \mathrm{s}^{-1}}\end{array}$ & $\begin{array}{c}\text { High flows } \geq \\
23 \mathrm{~m}^{3} . \mathrm{s}^{-1}\end{array}$ \\
\cline { 2 - 7 } \multicolumn{1}{c|}{} & KGE & bias & RMSE & \multicolumn{3}{c|}{ RMSE } \\
\hline KaRaMel+ Bucket & 0.92 & -0.11 & 4.59 & 1.96 & 3.69 & 7.21 \\
\hline KaRaMel+ SimpKcET & 0.95 & 0.08 & 3.41 & 1.02 & 2.81 & 5.40 \\
\hline
\end{tabular}

Monthly variabilities of ET, recharges and discharge of he hydrosystem were linked to the type of evapotranspiration model (Figure 12). The evapotranspiration simulated with SimpKcET (ETsimp) was usually slightly lower tha $t^{+1}$, e evapotranspiration simulated with the bucket (ETbu) model in autumn, winter nd spririg. On the contrary, ETsimp was higher than ETbu from late spring to late summer. licis difference in evapotranspiration dynamics induced differences in the hydrosyc « $\eta$ 's recharge volumes. Winter and spring refills were slightly higher with KaRaMel + Sir، N $^{\prime} \mathrm{CL}_{L}{ }^{\prime}$ and provided greater support for the hydrosystem's low water levels in summer ( $f$, ,per,dix B). However, the hydrosystem was mostly recharged in winter and spring, whatcer ine evapotranspiration model used. In summer the recharge rate was close to zorc ani recharge only occurs during high intensity rainfall events. Recharge became signifi ant again at the beginning of fall when the first major rainfall events occurred. At that time the simulated recharge was significantly lower with SimpKcET than with the bucket model. Conversely, SimpKcET simulated higher recharge events during the following months till spring. These changes in simulated recharge time dynamics directly impacted the simulated discharge which was decreased in autumn and winter and increased in spring when using SimpKcET. The resulting dynamic of simulated discharge was significantly improved with SimpKcET. 

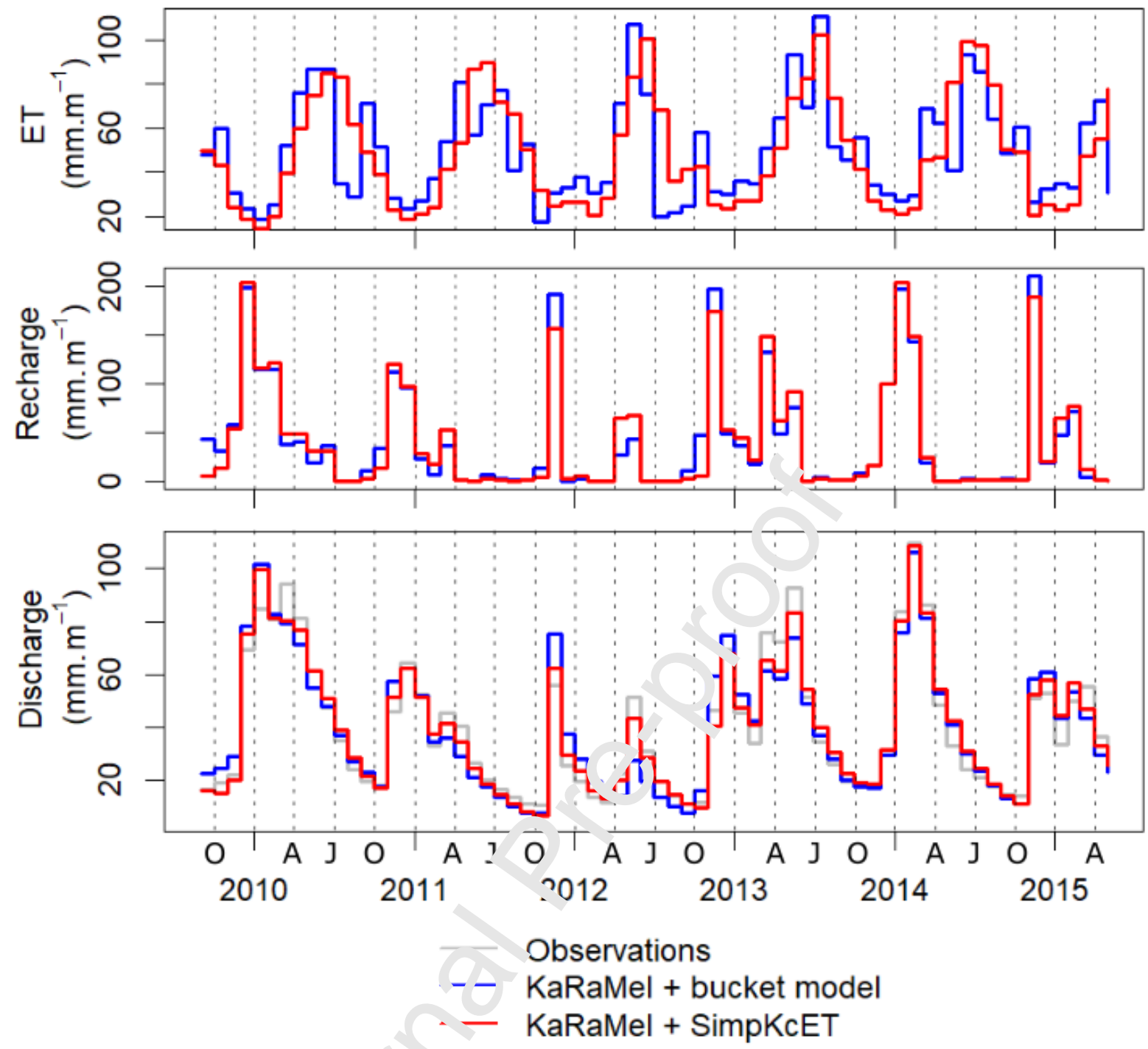

Figure 12: Monthly time serins of evapotranspiration, recharge and outlet discharge of Fontaine de Vaucluse 1quifer depending on the evapotranspiration model (bucket or SimpKcET). O: October, $\therefore$ April, J: July.

\subsubsection{Recharge and discharge relationship}

Cross wavelet spectrum (XWT) and cross wavelet coherence (WTC) analysis are used to highlight the relationships between simulated recharge and observed discharge (Qobs) signals (Figure 13). The recharge is simulated with the KaRaMel model using the bucket model (Rbu) or the SimpKcET model (Rsimp). On the cross-wavelet spectrum (XWT), the $y$ axis represents the frequencies expressed in periods (in days) and the $x$-axis the time. The colour bars represent the value of the wavelet coefficient with low to high powers (from blue to red). These analyses enable to identify whether the use of the SimpKcET model in a 
karst hydrological model provides more coherence between the hydrosystem's input and output signals compared to the use of the bucket model.

The XWT between Rbu and Qobs or Rsimp and Qobs have similar patterns (Figure 13-a, b). For periods of 2 to 64 days ( $y$-axis), times without linear relationships alternate with times of strong linear relationships between recharge and discharge. This corresponds to the seasonality of the recharge, during the wet season, the causal link between recharge and discharge is linear, while during the dry season the link is almost non-existent since recharge is low or nil. Comparison of the cross-wavelet coherence analyses (WTC) proves that the correlation is more intense with Rsimp than with Rbu (figure $1-c$, d). The calculation of the mean coherence by period reveals that the use of SimpKcET moc el brings improvements for mid-term components with periods greater than $100 \mathrm{da} / \mathrm{s}$ (: 3 months). It is also true for shorter periods, as for recharge events of year 2017 a limited by the white rectangle in Figure 13. Year 2012 was particularly dry but two 11. , ortant recharge events occurred in May. The first event happened from April 28t l :c May 4th with $35 \mathrm{~mm}$ of recharge. The second event happened from the 20th tr the ?.4th of May with $25 \mathrm{~mm}$ of recharge. Cross wavelet analysis highlighted a better corrc ' ttion between discharge observations with Rsimp than with Rbu (Figure 13-a, b). Mort vver, this relationship is more intense with Rsimp (Figure 13-c, d).

Previous results have shown hat Rsimp seems more realistic in quantitative terms, and shifts the start of recharge timt $;$ by a few weeks. Wavelet analysis adds that the simulated recharge is more corre atec with the observed discharge when it is simulated with the SimpKcET model. Howev ?r, the seasonal dynamics of recharge remain globally the same since it is imposed by the rainfall regime and the aquifer has no exchange with neighbouring 
aquifers.

a) XWT $R_{\text {bu }}$ vs $Q_{\text {obs }}$

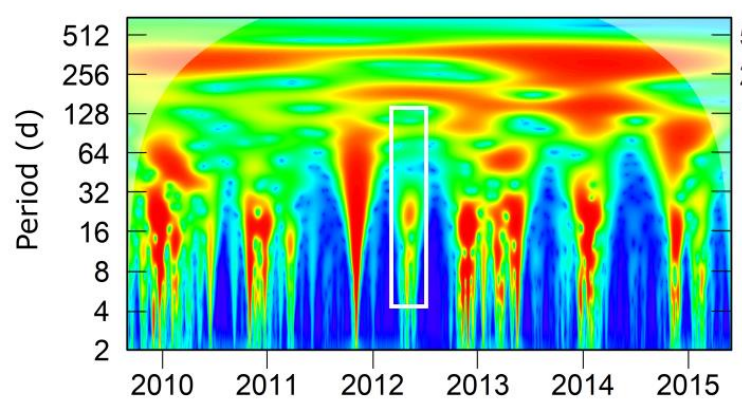

c) WTC $R_{\text {bu }}$ vs $Q_{\text {obs }}$

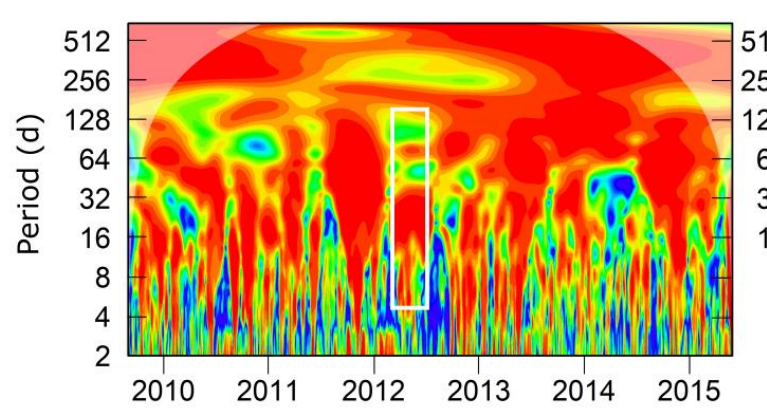

b) XWT $R_{\text {simp }}$ vs $Q_{\text {obs }}$

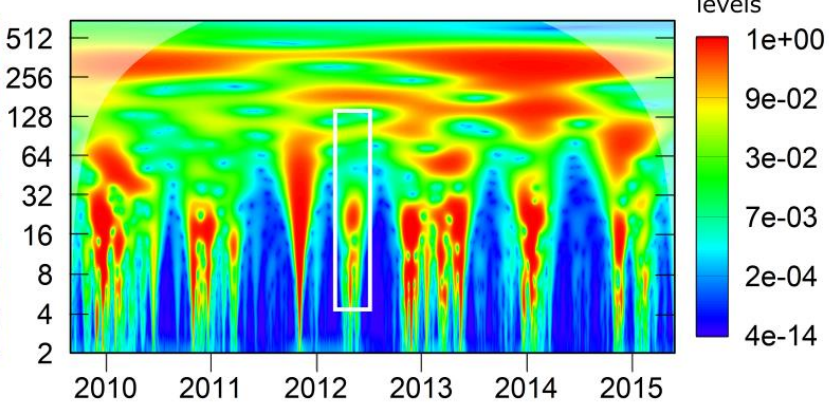

d) WTC R $R_{\text {simp }}$ vs $Q_{\text {obs }}$

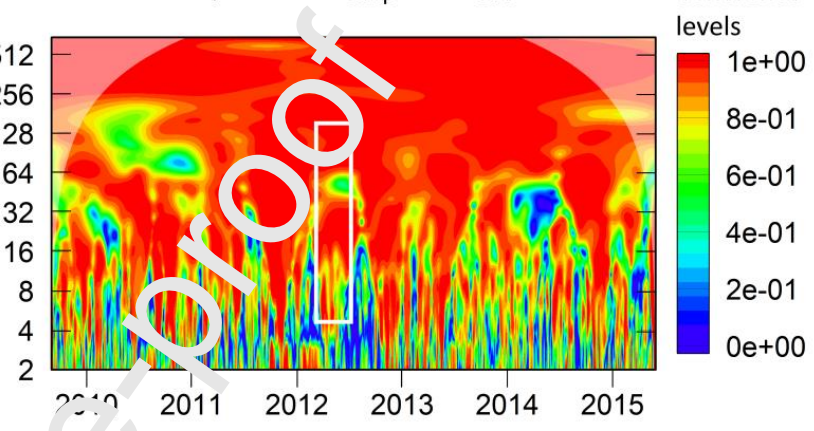

Figure 13: Cross wavelet analysis betwer." mu delled recharge signals (either Rbu or Rsimp depending on the evapotranspiration mu. ol) and discharge measures of the outlet of the aquifer (Qobs). a) and b) Cross waveleı spectrum (XWT), c) and d) cross wavelet coherence spectrum (WTC). The white rectanale de limits an area where both the linear relationship and the intensity of this relationshik $a_{1}$ ? stronger with Rsimp than with $R u$.

\section{Discussions}

Mediterranean karst laniscapes are characterised by diverse land uses with agricultural areas and areas of wild vegetation. The vegetation is formed by forests with a diversity of tree species, which are well-adapted to periodic water stress. The soils are often poorly developed and rich in stones. The SimpKcET model was developed to introduce a realistic description that accounts of the main evapotranspiration processes in karst hydrological modelling under Mediterranean climate. The need to integrate a more realistic evapotranspiration model for the evaluation of underground reserves in karst regions was also raised by Jódar et al. [2018] and Sarrazin et al. [2018]. The evapotranspiration models they proposed are more complex and require more parameters describing soil water 
transfer and retention (much more in the model of Sarrazin et al. [2018]). Most of vegetation parameters may be approximated after data recorded by vegetation ecophysiological monitoring [Lin et al., 2015] or calibrated after evapotranspiration measurement [as provided by FLUXNET network, Baldocchi et al., 2001, Chu et al., 2017], even if strong assumptions must be made for mixed forests and land cover. However, most of the uncertainties in their models are due to soil properties that remain challenging to estimate because they are highly variable at a short scale. The sensitivity analysis conducted by Sarrazin et al. [2018] shows that the first uncertainty factor in recharge estimation is the spatial variability factor of soil properties, followed by soil troperties. The results of the sensitivity analysis led by Garrigues et al. [2015] demonstr ate that the uncertainty of the spatial and temporal variability of evapotranspiration fro. 11 . vic soil properties. Ollivier et al. [2020] observes that the "strıpution of the SAWC has a strong influence on the discharge modelling of the Fontair. de Vaucluse hydrosystem. We assume that the estimation of evapotranspiration is mor = эppropriate with a conceptual model than with a physical model as long as the properti ss u. che soil cannot be known at any point in space.

In a first step, the SimpKcET model v. ?s evaluated against evapotranspiration records of three sites with different land cover. Ig' Icultural field, mixed forest of oak and pine, and oak forest, located southeast if France under a Mediterranean climate. The daily evapotranspiration simulatea 'v/Li SimpKcET were of good quality with an RMSE of about $0.5 \mathrm{~mm} . \mathrm{d}^{-1}$ at ET measl'c. neı, sites without calibration. In a second step, the SimpKcET model was implemente. Irıo the Karst Recharge and Discharge Model (KaRaMel) in order to evaluate the impact of evapotranspiration distribution on the discharge of the karst aquifer of Fontaine de Vaucluse. The original KaRaMel was using the bucket model to evaluate the evapotranspiration [Ollivier et al., 2020].

The evapotranspiration simulated with SimpKcET is significantly lower than climate demand (ETo, estimated using the Penman-Monteith equation). This contrasts with the simulated evapotranspiration with the bucket model, which was equal to ETo as long as there are water reserves in the soil, and soil water is readily consumed. SimpKcET has made it possible to simulate the regulation of evapotranspiration, which is particularly important during the hottest season. In the Mediterranean climate, climatic demand and plant activity are high in 
summer but water scarcity limits both transpiration and evaporation. This drastic limitation of evapotranspiration is correctly simulated by SimpKcET for local sites and for the studied watershed. The underground regulation of evapotranspiration, through the calculation of $k_{s}$, allows a more realistic simulation of the evolution of soil water, which is stored longer during the dry season than with the bucket model.

A specificity of SimpKcET lies in the introduction of the impact of the surface fraction of coarse elements on evaporation through the $f_{\text {rocks }}$ parameter. Indeed, karst superficial zones are often dominated by areas with large proportions of coarse elements and/or denuded carbonate rocks that limit soil surface evaporation. We showe: that the impact of the $f_{\text {rocks }}$ parameter is high except during the dry period and thai it; responsible for reducing significantly soil evaporation, in particular over the two loca forest sites. In consequence, $f_{\text {rocks }}$ has also a significant impact on the aquifer recharre. Thanks to the inclusion of the $f_{\text {rocks }}$ parameter, SimpKcET is well adapted to the simula: in of evapotranspiration over Karst systems that have poorly developed soils and a ir.ited amount of soil evaporation compared to transpiration.

Given the limited available data to describe -oil and vegetation at large scale, the proposed SimpKcET uses few parameters eas::; ir.plemented for all types of landscape. Moreover, some parameters, as $\mathrm{K}_{\mathrm{c}, \max }$ and $\mathrm{k}_{1}, \mathrm{x}^{\prime} \mathrm{e}_{\mathfrak{\prime}}$ - given constant values over the watershed as no real reference values existed for th din'arent ecosystems and soils. These values were providing good results over differert ecusystems at local sites (wheat in Avignon, holm oaks in Puechabon and mixed $\mathrm{h}, \mathrm{lm}$ raks and aleppo pines in FontBlanche) and were the used at the watershed level.

We observed differences between $\mathrm{SAWC}_{0}$ derived from soil pits analysis and SAWC values derived in previous local studies for the two forests in Puechabon and Font-Blanche. The $\mathrm{SAWC}_{0}$ values obtained from soil pits in the vicinity of the Font-Blanche and Puechabon sites are respectively in the range of 40 to $80 \mathrm{~mm}$ and 30 to $70 \mathrm{~mm}$, while the local values from earlier studies are 145-170 mm (Marie and Simioni [2014], Simioni et al. [2016]) and $120 \mathrm{~mm}$ (Allard et al. [2008]). Soils are very rich in coarse elements and the carbonate bedrock is very close to the surface which limits the depth of investigation of the soil pits that are usually dug by manual force. In a similar environment, Rambal et al. [2003] and Rambal [1984] 
showed that the deep roots of holm oak and kermes oak (a close relative of holm oak) allow them to exploit water in the sub-soil at least up to 4.5 metres, with an accessible water reserve between 300 and $450 \mathrm{~mm}$. Nourtier et al. [2014] showed that silver firs in the northern part of the Ventoux mountain were withdrawing water as deep as $4 \mathrm{~m}$ and possibly further in some part of the area. Carrière et al. [2020a] has proved by isotopic monitoring that during dry summers, a noticeable part of the water consumed by the trees comes from deep reservoir underground.

The SAWC deduced from the soil pits of natural areas therefore does not allow the assessment of the amount of water available for plant transpirc ion deeper in the sub-soil. In addition, several studies also showed the presence of ere inial water stocks in the unsaturated karst zone [e.g. Carrière et al., 2016, Pronk tt a 2009, Watlet et al. 2018]. As

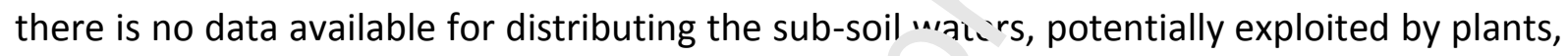
the same value has been assigned to all areas cov ed by natural ecosystems (forests, pastures). While cropped area were mainly pre $e^{r}, t$ over well-developed soil. Valley bottom, flat areas or zones with significant karr: decalcification clays and other sediments, sulting from erosion. The sub-soil water available for plants, the proportion of coarse ele nents and rocks at the soil surface were calibrated at catchment scale to $194 \mathrm{~mm}$ and $2 \sigma^{-} \%$ espectively. When compared to the total SAWC in Puechabon or FontBlanche, thi. SAWCadd value looks high. However, $200 \mathrm{~mm}$ would correspond to a water holdin 6 capacity of $5 \%$ for 4 meters layer which is in agreement with values observed in other in'sı systems in South of France as Rambal [1984]. It is difficult to evaluate the fraction oi rocks over the watershed as this fraction varies strongly from place to place, between 0 and $100 \%$. However, with large areas having high frocks, see for instance aerial photography of Appendix C.

At the moment, it is only possible to provide overall values of SAWCadd and frocks that were obtained through model calibration. This seems to be the wisest solution as long as soil properties are not mapped, which may be different in the future, as the international community is working to improve soil property maps in particular based on satellite information (see Arrouays et al. [2017] for example). It is likely that a better spatial distribution of soil properties would improve the realism of simulated evapotranspiration. Sensitivity studies of evapotranspiration models show the preponderance of simulation 
sensitivity to soil parameters [Garrigues et al., 2015, Sarrazin et al., 2018] and the hydrological model KaRaMel is also sensitive to the distribution of SAWC [Ollivier et al., 2020]. However, it is also likely that the low spatial resolution of climate data masks some of the spatial heterogeneity of evapotranspiration. Here, we used the SAFRAN data from METEO-FRANCE which are distributed on an $8 \mathrm{~km}$ by $8 \mathrm{~km}$ grid. This is the best spatial resolution available at the moment in France over long periods of time, but it may be not fine enough to resolve the spatial variability related to topography over our area. However, resolution may improve in the future with the increasing resolution of atmospheric models and the use of precipitation products derived from meteorolo ical radar measurements.

Since the use of SimpKcET allows a more realis ic imulation of watershed evapotranspiration, we expect that simulated hydrosyste $n$ flc ws, such as recharge, can also be more realistic. We have demonstrated the consisn $\iota^{+}$; between the simulated recharge and the observed discharge at the seasonal, annu ' and multi-year scales. The use of evapotranspiration with realistic daily, week $y$ and seasonal behaviours improves the modelling of daily recharge and discharge $; f_{1}$. Fontaine de Vaucluse aquifer. The Fontaine de Vaucluse aquifer has the following $c_{1}$. racteristics: karstic features are numerous (e.g. dolines, lapiaz), the karst network is we " developed, land use is mainly sparse forest, moors, scrubland, planted forests and agicul ural areas, and the impluvium is located under a Mediterranean climate. Such c. aracteristics are shared by many aquifers around the Mediterranean [Ford and Villia.ns, 2007]. The recharge and flow of the Fontaine de Vaucluse aquifer are rr.sp prosve to seasonal cycles and to the spatial distribution of evapotranspiration. Tri: is certainly the case for all hydrosystems that have similar characteristics. Thus, the application of a model as SimpKcET might benefit to improve the simulation of the flows within those other aquifers.

The SimpKcET model uses a conceptual representation of evaporation and transpiration processes which require a lower amount of information. The use of vegetation indices to constrain the fraction cover $\left(f_{\text {cover }}\right)$ makes it possible to avoid an exhaustive knowledge of the vegetation in place, and provide a better consideration of mixed cover. The vegetation indices (EVI) used have a coarser spatial resolution than those used by Jódar et al. [2018], but its temporal resolution is finer, allowing a better representation of the temporal dynamics of transpiration. Estimation of fraction cover from remote sensing data could be 
based on different algorithms (neural network, relation to vegetation indices...) and/or different satellite data (MODIS, VEGETATION/PROBA-V) that may affect the estimation of Kc [Gao et al. 2020]. Spectral properties of specific vegetation type can also affect the relation between vegetation indices and fcover [Carpintero et al. 2018]. Both these effects that could affect the estimation of ET were not investigated in our study which in a first step provided satisfactory results. Analysis of how changes in $\mathrm{f}_{\text {cover }}$ derivation can impact the derivation of ET using SimpKcET will be performed in further works. For example, we will investigate the possibility to derive $\mathrm{K}_{\mathrm{c}}$ from $\mathrm{f}_{\text {cover }}$ as obtained from the COPERNICUS Land Monitoring Service as this service directly provide $f_{\text {cover }}$ on a real time basis. Hov ever, it may provide different values of $f_{\text {cover }}$ compared to the values we derived in our wor'. a: involved algorithm are very different Copernicus product is based on a neural netv $v i$ trained on a large dataset of ground data, see Baret et al. [2013].

\section{Conclusions}

We proposed an evapotranspiration $\bmod _{-i}{ }^{+} h_{a}{ }^{2}$ enables a consistent representation of main processes (vegetation transpiration and s, il evaporation), with available parameters for all types of vegetation. The model consiste ncy was evaluated against the most commonly used model into hydrological models of kar st nydrosystem.

The SimpKcET model is based in tıle description of the soil's water retention capacity and the use of the fraction of $v$ :getation cover to simulate plant transpiration and soil evaporation. The use of rem ote sensing data, in particular the Enhanced Vegetation Index (EVI), enables an exhaust /e description of daily variation of vegetation development and its impact on evapotranspiration. The description of the soil reservoir is simple with only the soil available water capacity and the fraction of rocks of soil surface to determine, after ecological knowledge or soil pits observation, or to calibrate. Thanks to the inclusion of the frocks parameter that limits soil evaporation, the model is well adapted to the description of evaporation over karst systems.

SimpKcET was evaluated favourably against flux tower data on local sites in a first step and spring discharge of a large karst aquifer in a second step, showing that it enables the simulation of spatial and temporal variation of the evapotranspiration. Our results show the 
proximity between the daily estimates and the daily observations of evapotranspiration for forested and cultural field cover under a Mediterranean climate.

SimpKcET is applied at watershed scale under a Mediterranean climate (the karst aquifer of Fontaine de Vaucluse). It is an ideal test site with a wide range of land cover and landscape. The consideration of spatial and temporal distributions of soil evaporation and plant transpiration has an impact on recharge distribution, thus on the karst system answer. The use of SimpKcET model enables a more realistic estimation of the evapotranspiration and of the aquifer discharge, thus it is assumed that the simulated spatial and temporal recharge of the hydrosystem is also realistic. This is confirmed by the wav - let analysis of the rechargedischarge relationship. The use of a realistic evapotranspil łtio I induced more coherence between the simulated recharge and observed discharg ? at seasonal, year and multi-year scales. This experiment validates the use of the vege+ntı $n$ index from remote sensing data to estimate the evapotranspiration of a large watershe ${ }^{-1}$ with various land cover.

Different methods are available, but, at the $n \cdot n \in n t$, compared to the standard "working methods" in hydrogeology, the inclus in of ,emote sensed ET is "costly" (time, data handling, knowledge) [Jódar et al., 2018]. In context of global changes, it is very important now to provide operational ET prod ${ }_{n}$ ts 10 users with a quantification of uncertainties and adapted to the relevant time sc-ic a.ld spatial scales. The SimpKcET is robust for various land cover and can be easily : nplt.nented into hydrological models. This may improve the determination of effective qquiır recharge and in particular its time dynamics, as well as its spatial variability. The jc nt $\iota$ se of KaRaMel and SimpKcET allows a realistic simulation of the spatial and temporal dl:tribution of the system's recharge. This will help groundwater managers to better estimate the rate of renewal of the resource. An accurate estimate of the influence of surface properties (vegetation, land use, soil) is important in order to anticipate the impact of global changes on groundwater resources.

\section{Acknowledgements}

This work used eddy covariance data acquired and shared by the FLUXNET community, including these networks: Ameriflux, AfriFlux, AsiaFlux, CarboAfrica, CarboEuropelP, Carboltaly, CarboMont, ChinaFlux, Fluxnet-Canada, GreenGrass, ICOS, KoFlux, LBA, NECC, 
OzFlux-TERN, TCOS-Siberia, and USCCC. The ERA-Interim reanalysis data are provided by ECMWF and processed by LSCE. The FLUXNET eddy covariance data processing and harmonization was carried out by the European Fluxes Database Cluster, Ameriflux Management Project, and Fluxdata project of FLUXNET, with the support of CDIAC and ICOS Ecosystem Thematic Center, and the OzFlux, ChinaFlux and AsiaFlux offices.

We thank the investigators of the evapotranspiration monitoring sites for allowing us to use their data, and in particular Jean-Marc Ourcival (Puechabon).

The authors greatly thank Fred Baret for advices about the estimation of fraction cover from remote sensing data. The SAFRAN data were provided by MFTEC-FRANCE, and EVI data by NASA, we appreciate the support from Cécile Velluet and Fróci ri: i Huard (INRAE)

This work benefited from fruitful discussion within th: KARST observatory network (SNO KARST) initiative from the INSU/CNRS. SNO KARST rim, to strengthen knowledge sharing and to promote cross-disciplinary research on k- systems at the national scale.

Financial support for part of the study wa, r rov ided by CNES APR (Pitheas project) related to evapotranspiration estimation from remoı sensing data.

\section{References}

Allard, V., Ourcival, J.M., Ran.'al, J., Joffre, R., Rocheteau, A., 2008. Seasonal and annual variation of carbon excr ange in an evergreen Mediterranean forest in southern France. Global thai ge Biology 14, 714-725. https://doi.org/10.1111/i.1365$\underline{2486.2008 .01539 . \lambda}$

Allen, R.G., Pereira, L.S., 2009. Estimating crop coefficients from fraction of ground cover and height. Irrig Sci 28, 17-34. https://doi.org/10.1007/s00271-009-0182-z

Allen, R.G., Pruitt, W.O., Raes, D., Smith, M., Pereira, L.S., 2005. Estimating Evaporation from Bare Soil and the Crop Coefficient for the Initial Period Using Common Soils Information. J. Irrig. Drain Eng. 131, 14-23. https://doi.org/10.1061/(ASCE)07339437(2005)131:1(14)

Allen, R.G., Pereira, L.S., Raes, D., Smith, M., 1998. FAO Irrigation and drainage paper No. 56. Rome: Food and Agriculture Organization of the United Nations 56, e156. 
Allies, A., Demarty, J., Olioso, A., Bouzou Moussa, I., Issoufou, H.B.-A., Velluet, C., Bahir, M., Maïnassara, I., Oï, M., Chazarin, J.-P., Cappelaere, B., 2020. Evapotranspiration Estimation in the Sahel Using a New Ensemble-Contextual Method. Remote Sensing 12, 380. https://doi.org/10.3390/rs12030380

AnaEE, Analysis and Experiments on Ecosystems. https://www.anaee-france.fr/en/ (last accessed 07-01-2021)

Ardia, D., Boudt, K., Carl, P., Mullen, K., M., Peterson, B., G., 2011. Differential Evolution with DEoptim. The R Journal 3, 27. https://doi.org/10.32614/RJ-2011-005

Arrouays, D., Leenaars, J.G.B., Richer-de-Forges, A.C., Adhika K., Ballabio, C., Greve, M., Grundy, M., Guerrero, E., Hempel, J., Hengl, T., Heuve ink, G., Batjes, N., Carvalho, E., Hartemink, A., Hewitt, A., Hong, S.-Y., Krasilnik JV, P., Lagacherie, P., Lelyk, G., Libohova, Z., Lilly, A., McBratney, A., McKenzi: N., Vasquez, G.M., Mulder, V.L., Minasny, B., Montanarella, L., Odeh, I., Padar an, '., Poggio, L., Roudier, P., Saby, N., Savin, I., Searle, R., Solbovoy, V., Thompsor., J., Imith, S., Sulaeman, Y., Vintila, R., Rossel, R.V., Wilson, P., Zhang, G.-L., Swo, +„, M 1., Oorts, K., Karklins, A., Feng, L., Ibelles Navarro, A.R., Levin, A., Laktiono a, T., Tell'Acqua, M., Suvannang, N., Ruam, W., Prasad, J., Patil, N., Husnjak, S., Pás. +or, L., Okx, J., Hallett, S., Keay, C., Farewell, T., Lilja, H., Juilleret, J., Marx, S., Ta.'’ta, Y., Kazuyuki, Y., Mansuy, N., Panagos, P., Van Liedekerke, M., Skalsky, R., S',b ska, J., Kobza, J., Eftekhari, K., Alavipanah, S.K., Moussadek, R., Badraoui, M., Da Silva, M., Paterson, G., Gonçalves, M. da C., Theocharopoulos, S., Yəm, fack, M., Tedou, S., Vrscaj, B., Grob, U., Kozák, J., Boruvka, L., Dobos, E., Taboadá, M , Moretti, L., Rodriguez, D., 2017. Soil legacy data rescue via GlobalSoilMap zn' ot ıer international and national initiatives. GeoResJ 14, 1-19. https://doi.org/10.j J16/i.gri.2017.06.001

Baldocchi, D., Falge, E., Gu, L., Olson, R., Hollinger, D., Running, S., Anthoni, P., Bernhofer, Ch., Davis, K., Evans, R., Fuentes, J., Goldstein, A., Katul, G., Law, B., Lee, X., Malhi, Y., Meyers, T., Munger, W., Oechet, W., Paw U, K.T., Pilegaard, K., Schmid, H.P., Valentini, R., Verma, S., Vesala, T., Wilson, K., Wofsy, S., 2001. FLUXNET: A New Tool to Study the Temporal and Spatial Variability of Ecosystem-Scale Carbon Dioxide, Water Vapor, and Energy Flux Densitie. Bulletin of the American Meteorological Society 82, 24152434. https://doi.org/10.1175/1520-0477(2001)082<2415:FANTTS>2.3.CO;2 
Baret, F., Weiss, M., Verger, A., \& Smets, B. 2013. ATBD for LAI, fAPAR And Fcover From Proba-V Products At 300m Resolution (Geov3). IMAGINES_RP2.1_ATBD-LAI300M, ISSUE 1.73, EC Proposal Reference N FP7-311766

Bausch, W.C., 1993. Soil background effects on reflectance-based crop coefficients for corn. Remote Sensing of Environment 46, 213-222. https://doi.org/10.1016/0034$\underline{4257(93) 90096-G}$

Bausch, W.C., Neale, C.M.U., 1987. Crop Coefficients Derived from Reflected Canopy Radiation: A Concept. Transactions of the ASAE 30, 703-0709. https://doi.org/10.13031/2013.30463

Beck, H.E., Zimmermann, N.E., McVicar, T.R., Vergopolan, V., 3erg, A., Wood, E.F., 2018. Present and future Köppen-Geiger climate classific at/c $า$ maps at 1-km resolution. Sci Data 5, 180214. https://doi.org/10.1038/sdata.2C: 8.214

Bottner, P., 1971. Evolution des sols en milieu car^^r.até. La pédogenèse sur les roches calcaires dans une séquence bioclimatiqu' = néditerranéo-alpine du Sud de la France. Université Montpellier.

Breshears, D.D., Cobb, N.S., Rich, P.M., '‘ce, K.P., Allen, C.D., Balice, R.G., Romme, W.H., Kastens, J.H., Floyd, M.L., Belna, J., Anderson, J.J., Myers, O.B., Meyer, C.W., 2005. Regional vegetation die-off in $r f$ sp snse to global-change-type drought. Proceedings of the National Acider.y of Sciences 102, 15144-15148. https://doi.org/10.1073/ ^ nas.0505734102

Brutsaert, W., 1982. Evannr +: on into the atmosphere: theory, history, and applications. Kluwer, Dordrec't.

CARBOEUROPE-IP, 201y. Assessment of the european terrestrial carbon balance. URL: http://www.carboeurope.org. (last accessed: 24.12.2020)

Carlson, T.N., Ripley, D.A., 1997. On the relation between NDVI, fractional vegetation cover, and leaf area index. Remote Sensing of Environment 62, 241-252. https://doi.org/10.1016/S0034-4257(97)00104-1

Carpintero, E., González-Dugo, M.P., Jódar, J., Martos-Rosillo, S., 2018. Use of canopy coefficients obtained from satellite data to estimate evapotranspiration over high mountain Mediterranean watersheds. Proc. IAHS 380, 23-28. https://doi.org/10.5194/piahs-380-23-2018 
Carrière, S.D., Chalikakis, K., Danquigny, C., Davi, H., Mazzilli, N., Ollivier, C., Emblanch, C., 2016. The role of porous matrix in water flow regulation within a karst unsaturated zone: an integrated hydrogeophysical approach. Hydrogeology Journal. https://doi.org/10.1007/s10040-016-1425-8

Carrière, S.D., Ruffault, J., Cakpo, C.B., Olioso, A., Doussan, C., Simioni, G., Chalikakis, K., Patris, N., Davi, H., MartinSt-Paul, N.K., 2020a. Intra-specific variability in deep water extraction between trees growing on a Mediterranean karst. Journal of Hydrology 125428. https://doi.org/10.1016/i.jhydrol.2020.125428

Carrière, S.D., St-Paul, N.K.M., Cakpo, C.B., Patris, N., Gillon, 'M., Chalikakis, K., Doussan, C., Olioso, A., Babic, M., Jouineau, A., Simioni, G., Davi, H., nn? S. $_{\text {. The }}$ role of deep vadose zone water in tree transpiration during drought periods ${ }^{n}$ ' . arst settings - Insights from isotopic tracing and leaf water potential. Scier zt of The Total Environment 699, 134332. https://doi.org/10.1016/i.scitotenv.2010.1 s.:332

Charlier, J.-B., Bertrand, C., Mudry, J., 2012. Conce, Jtuaı hydrogeological model of flow and transport of dissolved organic carbon in $\exists-n$ a.l Jura karst system. Journal of Hydrology 460-461, 52-64. https://doi.org/11. 11 16 i ihydrol.2012.06.043

Charlier, J.-B., Ladouche, B., Maréchal, J.-C., 2015. Identifying the impact of climate and anthropic pressures on karst a 1 ife, $;$ using wavelet analysis. Journal of Hydrology 523, 610-623. https://doi.org/10.10 0 ¿ ji.jhydrol.2015.02.003

Chen, Z., Auler, A.S., Bakalowi - M., Drew, D., Griger, F., Hartmann, J., Jiang, G., Moosdorf, N., Richts, A., Stevanuvic, ‥, Veni, G., Goldscheider, N., 2017. The World Karst Aquifer Mapping project: con ept, mapping procedure and map of Europe. Hydrogeology Journal 25, 771-7૪_, https://doi.org/10.1007/s10040-016-1519-3

Choudhury, B.J., Ahmed, N.U., Idso, S.B., Reginato, R.J., Daughtry, C.S.T., 1994. Relations between Evaporation Coefficients and Vegetation Indices Studied by Model Simulations. Remote sens. environ. 1-17. https://doi.org/10.1016/0034$\underline{4257(94) 90090-6}$

Chu, H., Baldocchi, D.D., John, R., Wolf, S., Reichstein, M., 2017. Fluxes all of the time? A primer on the temporal representativeness of FLUXNET: fluxes all of the time? Journal of Geophysical Research: Biogeosciences 122, 289-307. https://doi.org/10.1002/2016JG003576 
Clobert, J., Chanzy, A., Le Galliard, J.-F., Chabbi, A., Greiveldinger, L., Caquet, T., Loreau, M., Mougin, C., Pichot, C., Roy, J., Saint-André, L., 2018. How to Integrate Experimental Research Approaches in Ecological and Environmental Studies: AnaEE France as an Example. Front. Ecol. Evol. 6, 43. https://doi.org/10.3389/fevo.2018.00043

COPERNICUS Land Monitoring Service: https://land.copernicus.eu/global/products/fcover (last accessed: 24.12 .2020$)$

Cramer, W., Bondeau, A., Woodward, F.I., Prentice, I.C., Betts, R.A., Brovkin, V., Cox, P.M., Fisher, V., Foley, J.A., Friend, A.D., Kucharik, C., Lomas, M.R., Ramankutty, N., Sitch, S., Smith, B., White, A., Young-Molling, C., 2001. Global res sonse of terrestrial ecosystem structure and function to $\mathrm{CO} 2$ and climate change: rr-1/l, from six dynamic global vegetation models. Global Change Biology 7, 357-372 , ${ }^{+++}$, s://doi.org/10.1046/i.1365$\underline{2486.2001 .00383 . x}$

Delaigue, O., Thirel, G., Bourgin, F., Coron, L., 2n 18 . 'atest developments of the airGR rainfall-runoff modelling $\mathrm{R}$ package: new calib atioı. procedures and other features.

Doorenbos, J., Pruitt, W.O., 1977. Guideliner for redicting crop water requirements. Food and Agriculture organization of $t^{\prime}$ e 1 nited nation. Irrigation and Drainage paper 24, 154.

Durand, Y., Laternser, M., Girauc, ง , Etchevers, P., Lesaffre, B., Mérindol, L., 2009. Reanalysis of $44 \mathrm{Yr}$ of Clin ate in the French Alps (1958-2002): Methodology, Model Validation, Climatology, and irends for Air Temperature and Precipitation. Journal of Applied Metecrolo;y and Climatology 48, 429-449. https://doi.org/10 117: /2008JAMC1808.1

EARTHDATA, 2019. The earth observing system data and information system. URL: https://search.earthdata.nasa.gov/search. (last accessed: 24.12.2020)

Farahani, H. J., Howell, T. A., Shuttleworth, W. J., \& Bausch, W. C. (2007). Evapotranspiration: progress in measurement and modeling in agriculture. Transactions of the ASABE, $50(5), 1627-1638$.

Fleury, P., Plagnes, V., Bakalowicz, M., 2007. Modelling of the functioning of karst aquifers with a reservoir model: Application to Fontaine de Vaucluse (South of France). Journal of Hydrology 345, 38-49. https://doi.org/10.1016/i.jhydrol.2007.07.014 
Fisher, J.B., Melton, F., Middleton, E., Hain, C., Anderson, M., Allen, R., McCabe, M.F., Hook, S., Baldocchi, D., Townsend, P.A., Kilic, A., Tu, K., Miralles, D.D., Perret, J., Lagouarde, J.-P., Waliser, D., Purdy, A.J., French, A., Schimel, D., Famiglietti, J.S., Stephens, G., Wood, E.F., n.d. The future of evapotranspiration: Global requirements for ecosystem functioning, carbon and climate feedbacks, agricultural management, and water resources. Water Resources Research 9.

Ford, D., Williams, P., 2007. Karst Hydrogeology and Geomorphology 30.

Gallego-Elvira, B., Olioso, A., Mira, M., Castillo, S.R.-, Boulet, G., Marloie, O., Garrigues, S., Courault, D., Weiss, M., Chauvelon, P., Boutron, O., 201?. EVASPA (EVapotranspiration Assessment from SPAce) Tool: An overview. Procedia En ir. mental Sciences 19, 303310. https://doi.org/10.1016/i.proenv.2013.06.035

Gao, L., Wang, X., Johnson, B.A., Tian, Q., Wang, Y., Vei: elst, J., Mu, X., Gu, X., 2020. Remote sensing algorithms for estimation of fractioná' veg ttation cover using pure vegetation index values: A review. ISPRS Journal of nhotogrammetry and Remote Sensing 159, 364-377. https://doi.org/10.1016/j.ispr ipı _._019.11.018

Garrigues, S., A. Boone, Decharme, B., Oi. so, A., Albergel, C., Calvet, J.-C., Moulin, S., Buis, S., Martin, E., 2018. Impacts $\iota^{c}$ the Soil Water Transfer Parameterization on the Simulation of Evapotranspiriti s, over a 14-Year Mediterranean Crop Succession. Journal of Hydrometeoroln sy 1 ? , 3-25. https://doi.org/10.1175/JHM-D-17-0058.1

Garrigues, S., Olioso, A., Calvt' J.こ., Martin, E., Lafont, S., Moulin, S., Chanzy, A., Marloie, O., Buis, S., Desfonds, '⿳. Bu crand, N., Renard, D., 2015. Evaluation of land surface model simulations of : $/ a_{r}{ }^{2}$ :ranspiration over a 12-year crop succession: impact of soil hydraulic and vere ation properties. Hydrology and Earth System Sciences 19, 31093131. https://doi.org/10.5194/hess-19-3109-2015

Girard, F., Vennetier, M., Guibal, F., Corona, C., Ouarmim, S., Herrero, A., 2012. Pinus halepensis Mill. crown development and fruiting declined with repeated drought in Mediterranean France. European Journal of Forest Research 131, 919-931. https://doi.org/10.1007/s10342-011-0565-6

Godard, V., Ollivier, V., Bellier, O., Miramont, C., Shabanian, E., Fleury, J., Benedetti, L., Guillou, V., 2016. Weathering-limited hillslope evolution in carbonate landscapes. 
Earth and Planetary Science Letters 446, 10-20. https://doi.org/10.1016/j.epsl.2016.04.017

González-Dugo, M.P., Mateos, L., 2008. Spectral vegetation indices for benchmarking water productivity of irrigated cotton and sugarbeet crops. Agricultural Water Management 95, 48-58. https://doi.org/10.1016/i.agwat.2007.09.001

Grippa, M., Kergoat, L., Boone, A., Peugeot, C., Demarty, J., Cappelaere, B., Gal, L., Hiernaux, P., Mougin, E., Ducharne, A., Dutra, E., Anderson, M., Hain, C., ALMIP2 Working Group, 2017. Modeling Surface Runoff and Water Fluxes over Contrasted Soils in the Pastoral Sahel: Evaluation of the ALMIP2 Land Surface Models ov ar the Gourma Region in Mali. Journal of Hydrometeorology 18, 1847-1866. http..//4.i.org/10.1175/JHM-D-16$\underline{0170.1}$

Gupta, H.V., Kling, H., Yilmaz, K.K., Martinez, G., 2009. ')ecumposition of the mean squared error and NSE performance criteria: Implicatic is fc r improving hydrological modelling. Journal of Hydrology 377, 80-91. https://doi.crg/1i.1016/i.jhydrol.2009.08.003

Hargreaves, G.H., Allen, R.G., 2003. History ar d tvaluation of Hargreaves Evapotranspiration Equation. J. Irrig. Drain Eng. 12c , 53-63. https://doi.org/10.1061/(ASCE)07339437(2003)129:1(53)

Hargreaves, G. H., \& Samani, Z /. (1985). Reference crop evapotranspiration from temperature. Applied ercineering in agriculture, 1(2), 96-99. doi: $10.13031 / 2013.26773$

Hartmann, A., Gleeson, T h:-olem, R., Pianosi, F., Wada, Y., Wagener, T., 2015. A largescale simulatioı, $\mathrm{midr}$, to assess karstic groundwater recharge over Europe and the Mediterranean. Fe ssci. Model Dev. 8, 1729-1746. https://doi.org/10.5194/gmd-8$\underline{1729-2015}$

Hartmann, A., Goldscheider, N., Wagener, T., Lange, J., Weiler, M., 2014. Karst water resources in a changing world: Review of hydrological modeling approaches. Reviews of Geophysics 52, 218-242. https://doi.org/10.1002/2013RG000443

Hartmann, A., Lange, J., Weiler, M., Arbel, Y., Greenbaum, N., 2012. A new approach to model the spatial and temporal variability of recharge to karst aquifers. Hydrology and Earth System Sciences 16, 2219-2231. https://doi.org/10.5194/hess-16-2219-2012 
Heilman, J.L., Heilman, W.E., Moore, D.G., 1982. Evaluating the Crop Coefficient Using $\begin{array}{lllll}\text { Spectral } & \text { Reflectance1. } & \text { Agronomy }\end{array}$ https://doi.org/10.2134/agronj1982.00021962007400060010x

Helman, D., Givati, A., Lensky, I.M., 2015. Annual evapotranspiration retrieved from satellite vegetation indices for the eastern Mediterranean at $250 \mathrm{~m}$ spatial resolution. Atmospheric Chemistry and Physics 15, 12567-12579. https://doi.org/10.5194/acp-15$\underline{12567-2015}$

Hu, K., Chen, H., Nie, Y., Wang, K., 2015. Seasonal recharge and mean residence times of soil and epikarst water in a small karst catchment of southu est China. Scientific Reports 5, 10215. https://doi.org/10.1038/srep10215

Huete, A.R., 1988. A soil-adjusted vegetation index (SAV'1. $n$ 'mote Sensing of Environment 25, 295-309. https://doi.org/10.1016/0034-4257'“8)yu106-X

Huete, A., Justice, C., Liu, H., 1994. Development of 'oretation and soil indices for MODISEOS. Remote Sensing of Environment 49, ?.<- -234.

Huete, A., Didan, K., Miura, T., Rodriguez - P., Fao, X., Ferreira, L.G., 2002. Overview of the radiometric and biophysical perfor : ance of the MODIS vegetation indices. Remote sensing of environment 83, 195-?13.

Huete, A., Didan, K., van Leeuwen W . Miura, T., Glenn, E., 2010. MODIS Vegetation Indices, in: Ramachandran, B., J'si:e, C.O., Abrams, M.J. (Eds.), Land Remote Sensing and Global Environmental Tha.nge. Springer New York, New York, NY, pp. 579-602. https://doi.org/10.1nn, is 78-1-4419-6749-7 26

ICOS, Integrated Carbol, Onservation System, monitoring networks of the greenhouse gases in the atmosphere, oceans and continents https://www.icos-france.fr/en (last accessed 07-01-2021)

Jensen, M.E., Burman, R.D., Allen, R.G., 1990. Evapotranspiration and irrigation water requirements. ASCE.

Jódar, J., Carpintero, E., Martos-Rosillo, S., Ruiz-Constán, A., Marín-Lechado, C., CabreraArrabal, J.A., Navarrete-Mazariegos, E., González-Ramón, A., Lambán, L.J., Herrera, C., González-Dugo, M.P., 2018. Combination of lumped hydrological and remote-sensing models to evaluate water resources in a semi-arid high altitude ungauged watershed 
of Sierra Nevada (Southern Spain). Science of The Total Environment 625, 285-300. https://doi.org/10.1016/i.scitotenv.2017.12.300

Jung, H.C., Getirana, A., Arsenault, K.R., Holmes, T.R.H., McNally, A., 2019. Uncertainties in Evapotranspiration Estimates over West Africa. Remote Sensing 11, 892. https://doi.org/10.3390/rs11080892

Kandasamy, S., Baret, F., Verger, A., Neveux, P., \& Weiss, M. 2013. A comparison of methods for smoothing and gap filling time series of remote sensing observations-application to MODIS LAI products. Biogeosciences, 10(6), 4055-4071. doi:10.5194/bg-10-4055-2013

Kimball, B., Boote, K., Hatfield, J., Ahuja, L., Stockle, C., Archori ulis, S., Baron, C., Basso, B., Bertuzzi, P., Chen, M., Constantin, J., Derying, D., Dur onı, B., Durand, J.-L., Ewert, F., Gaiser, T., Gayler, S., GRIFFIS, T., Hoffmann, M., Jiar g, `., Kim, S.-H., Lizaso, J., Moulin, S., Nendel, C., Parker, P., Palosuo, T., Priesack, E., ' 'i Z., Z., Srivastava, A., Stella, T., Tao, F., Thorp, K., Timlin, D., Twine, T., Webber. H., Willaume, M., Williams, K., 2017. Prediction of Evapotranspiration and Yields ci Máize: An Inter-comparison among 31 Maize Models, in: Meeting of Working Gr up Medicago Sativa. Tampa , United States, p. 1. https://hal.inria.fr/hal-029503's

Kite, G.W., Kouwen, N., 1992. W'atershed modeling using land classification. Water Resources Research 28, 3193-;270. https://doi.org/10.1029/92WR01819

Kumar, P., Foufoula-Georgiou, F, 1:97. Wavelet analysis for geophysical applications. Rev. Geophys. 35, 385-412. hi_'ns://doi.org/10.1029/97RG00427

Labat, D., Ababou, R., Mangा।., A., 2000a. Rainfall-runoff relations for karstic springs. Part I: convolution a. $d$ crectral analyses. Journal of Hydrology 238, 123-148. https://doi.org/1 . ${ }^{1}$ J16/S0022-1694(00)00321-8

Labat, D., Ababou, R., Mangin, A., 2000b. Rainfall-runoff relations for karstic springs. Part II: continuous wavelet and discrete orthogonal multiresolution analyses. Journal of hydrology 238, 149-178. https://doi.org/10.1016/S0022-1694(00)00322-X

Labat, D., 2005. Recent advances in wavelet analyses: Part 1. A review of concepts. Journal of Hydrology 314, 275-288. https://doi.org/10.1016/i.jhydrol.2005.04.003

Labat, D., 2010. Cross wavelet analyses of annual continental freshwater discharge and selected climate indices. Journal of Hydrology 385, 269-278. https://doi.org/10.1016/j.jhydrol.2010.02.029 
Ladouche, B., Marechal, J.-C., Dorfliger, N., 2014. Semi-distributed lumped model of a karst system under active management. Journal of Hydrology 509, 215-230. https://doi.org/10.1016/i.jhydrol.2013.11.017

Li, W., Weiss, M., Waldner, F., Defourny, P., Demarez, V., Morin, D., Hagolle, O., Baret, F., 2015. A Generic Algorithm to Estimate LAI, FAPAR and FCOVER Variables from SPOT4_HRVIR and Landsat Sensors: Evaluation of the Consistency and Comparison with Ground Measurements. Remote Sensing 7, 15494-15516. https://doi.org/10.3390/rs71115494

Lin, Y.-S., Medlyn, B.E., Duursma, R.A., Prentice, I.C., Wang, F'., Baig, S., Eamus, D., de Dios, V.R., Mitchell, P., Ellsworth, D.S., de Beeck, M.O., Wallir, G., Uddling, J., Tarvainen, L., Linderson, M.-L., Cernusak, L.A., Nippert, J.B., Ocheltı_, T.W., Tissue, D.T., MartinStPaul, N.K., Rogers, A., Warren, J.M., De Angelis, F., H' cosaka, K., Han, Q., Onoda, Y., Gimeno, T.E., Barton, C.V.M., Bennie, J., Bonal L. Losc, A., Löw, M., Macinins-Ng, C., Rey, A., Rowland, L., Setterfield, S.A., Tan.z-Posch, S., Zaragoza-Castells, J., Broadmeadow, M.S.J., Drake, J.E., Freer 1a'ı, M., Ghannoum, O., Hutley, L.B., Kelly, J.W., Kikuzawa, K., Kolari, P., Koyama ì Limousin, J.-M., Meir, P., Lola da Costa, A.C., Mikkelsen, T.N., Salinas, N., Sun, 1. Wingate, L., 2015. Optimal stomatal behaviour around the world. Nature Climate Change 5, 459. https://doi.org/10.1038/nclim at 2 ?50

Liu, S., Huang, S., Xie, Y., Waric H., Huang, Q., Leng, G., Li, P., Wang, L., 2019. Spatialtemporal changes in vege $a t i o n$ cover in a typical semi-humid and semi-arid region in China: Changing patte.ns causes and implications. Ecological Indicators 98, 462-475. https://doi.org,'10.101'/j.ecolind.2018.11.037

Marie, G., Simioni, G., Z014. Extending the use of ecological models without sacrificing details: a generic and parsimonious meta-modelling approach. Methods in Ecology and Evolution 5, 934-943. https://doi.org/10.1111/2041-210X.12250

Martens, B., Miralles, D.G., Lievens, H., Fernández-Prieto, D., Beck, H.E., Dorigo, W.A., Verhoest, N.E.C., 2017. GLEAM v3: satellite-based land evaporation and root-zone soil moisture. Geosci. Model Dev. 23. 10.5194/gmd-10-1903-2017

McBratney, A.B., Mendonça Santos, M.L., Minasny, B., 2003. On digital soil mapping. Geoderma 117, 3-52. https://doi.org/10.1016/S0016-7061(03)00223-4 
McDonald, J.E., 1961. On the Ratio of Evaporation to Precipitation. Bulletin of the American Meteorological Society 42, 185-189. https://doi.org/10.1175/1520-0477-42.3.185

Melton, F.S., Johnson, L.F., Lund, C.P., Pierce, L.L., Michaelis, A.R., Hiatt, S.H., Guzman, A., Adhikari, D.D., Purdy, A.J., Rosevelt, C., Votava, P., Trout, T.J., Temesgen, B., Frame, K., Sheffner, E.J., Nemani, R.R., 2012. Satellite Irrigation Management Support With the Terrestrial Observation and Prediction System: A Framework for Integration of Satellite and Surface Observations to Support Improvements in Agricultural Water Resource Management. IEEE Journal of Selected Topics in Applied Earth Observations and Remote Sensing 5, 1709-1721. https://doi.org/10.1109/JSTARS.2012.2214474

Messerschmid, C., Sauter, M., Lange, J., 2020. Field-based ssi.nation and modelling of distributed groundwater recharge in a Mediterranean 1, . st catchment, Wadi Natuf, West Bank. Hydrol. Earth Syst. Sci. 24, 887-917. $t_{t} \imath_{r} \times 1 /$ doi.org/10.5194/hess-24-887$\underline{2020}$

Moreira, A.A., Ruhoff, A.L., Roberti, D.R., Souza, V. de r.., da Rocha, H.R., Paiva, R.C.D. de, 2019. Assessment of terrestrial water b'an:e using remote sensing data in South $\begin{array}{llll}\text { America. Journal } & \text { c. Hydrology 131-147. }\end{array}$ https://doi.org/10.1016/i.jhydrol.20_ ${ }^{2} \cdot 05.021$

Mu, Q., Heinsch, F.A., Zhao, M., Running, S.W., 2007. Development of a global evapotranspiration algorith $\cdots b_{c}$ ad on MODIS and global meteorology data. Remote Sensing of Environment 111, 519-536. https://doi.org/10.1016/i.rse.2007.04.015

Mu, Q., Zhao, M., Runni.'o, ..W., 2011. Improvements to a MODIS global terrestrial evapotranspiratior aly orithm. Remote Sensing of Environment 115, 1781-1800. https://doi.org/10.: 016/j.rse.2011.02.019

Nourtier, M., Chanzy, A., Cailleret, M., Yingge, X., Huc, R., Davi, H., 2014. Transpiration of silver Fir (Abies alba mill.) during and after drought in relation to soil properties in a Mediterranean mountain area. Annals of Forest Science 71, 683-695. https://doi.org/10.1007/s13595-012-0229-9

Olioso, A., Lecerf, R., Chanzy, A., Ruget, F., Huard, F.F., Baillieux, A., Rossello, P., Lecharpentier, P., Trolard, F., Charron, F., Ruy, S., Alkassem-Alosman, M., CognardPlancq, A.-L., Seguin, B., Courault, D., Gallego-Elvira, B., Garrigues, S., 2013. Bilan hydrique des agrosystèmes de Crau face aux changements globaux., in: Ecologie et Conservation d'une Steppe Méditerranéenne. La Plaine de Crau. 
Olioso, A., Ollivier, C., Martin-StPaul, N.K., Simioni, G., Weiss, M., Guillevic, P., Marloie, O., Carrière, S.D., Davi, H., Huard, F., 2019. Monitoring Vegetation Fraction Cover of French Mediterranean Forests for Evapotranspiration and Water Stress Mapping. Presented at the Living Planet Symposium, Milan.

Ollivier, C., 2019. Caractérisation et spatialisation de la recharge des hydrosystèmes karstiques: Application à l'aquifère de Fontaine de Vaucluse, France (PhD Thesis). Avignon Université, Avignon. https://tel.archives-ouvertes.fr/tel-02614260

Ollivier, C., Mazzilli, N., Olioso, A., Chalikakis, K., Carrière, S.D., Danquigny, C., Emblanch, C., 2020. Karst recharge-discharge semi distributed model to assess spatial variability of flows. Science of The Total Envirnnmint 703, 134368. https://doi.org/10.1016/i.scitotenv.2019.134368

Oudin, L., 2004. Recherche d'un modèle d'évapotrans $s_{\uparrow}^{i}$ ratıon potentielle pertinent comme entrée d'un modèle pluie-débit glok al. ENGREF (AgroParisTech). https://pastel.archives-ouvertes.fr/pastel-000 J09s:

Oudin, L., Hervieu, F., Michel, C., Perrin, C., A Idréassian, V., Anctil, F., Loumagne, C., 2005a. Which potential evapotranspiratic 1 in sut for a lumped rainfall-runoff model? Part 2Towards a simple and efficien+ potencial evapotranspiration model for rainfall-runoff modelling. Journal if Hydrology 303, 290-306.

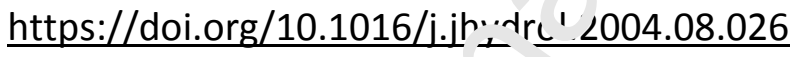

Oudin, L., Michel, C., Anctil, $\ulcorner$, 2005b. Which potential evapotranspiration input for a lumped rainfall-runo if mudel? Part 1-Can rainfall-runoff models effectively handle detailed potential evé jotranspiration inputs? Journal of Hydrology 303, 275-289. https://doi.org/10. 016/j.jhydrol.2004.08.025

Pachepsky, Ya.A., Timlin, D., Varallyay, G., 1996. Artificial Neural Networks to Estimate Soil Water Retention from Easily Measurable Data. Soil Science Society of America Journal 60, 727. https://doi.org/10.2136/sssaj1996.03615995006000030007x

Perrin, C., Michel, C., Andréassian, V., 2003. Improvement of a parsimonious model for streamflow simulation. Journal of Hydrology 279, 275-289. https://doi.org/10.1016/S0022-1694(03)00225-7 
Pronk, M., Goldscheider, N., Zopfi, J., Zwahlen, F., 2009. Percolation and Particle Transport in the Unsaturated Zone of a Karst Aquifer. Ground Water 47, 361-369. https://doi.org/10.1111/i.1745-6584.2008.00509.x

Qi, J., Chehbouni, A., Huete, A.R., Kerr, Y.H., Sorooshian, S., 1994. A modified soil adjusted vegetation index. Remote Sensing of Environment 48, 119-126. https://doi.org/10.1016/0034-4257(94)90134-1

Quintana-Seguí, P., Le Moigne, P., Durand, Y., Martin, E., Habets, F., Baillon, M., Canellas, C., Franchisteguy, L., Morel, S., 2008. Analysis of Near-Surface Atmospheric Variables: Validation of the SAFRAN Analysis over France. Journa' of Applied Meteorology and Climatology 47, 92-107. https://doi.org/10.1175/2007J^^1C:536.1

Rahman, M., Rosolem, R., 2017. Towards a simple repres „nu tion of chalk hydrology in land surface modelling. Hydrol. Earth Syst. Sci. 21, 45:-4/1. https://doi.org/10.5194/hess$\underline{21-459-2017}$

Rambal, S., 1982. Variabilité des propriétés hyd v. 'ynamiques du sol à l'échelle d'un versant karstique. Presented at "the Variabilit: spaciale des processus de transfert dans les sols", INRA, Avignon, pp. 201-211

Rambal, S., 1984. Water balance and $₹$ attern of root water uptake by a Quercus coccifera L. evergreen scrub. Oecologia $1 \varepsilon-7.3$

Rambal, S., 1992. Quercus ilex '7cing water stress: a functional equilibrium hypothesis. Vegetatio 99, 147-153. 'ttrs://doi.org/10.1007/BF00118220

Rambal, S., 1993. The d $_{1}{ }^{\text {fferential }}$ role of mechanisms for drought resistance in a Mediterranean ev rgreen shrub: a simulation approach. Plant Cell Environ 16, 35-44. https://doi.org/1U.1111/j.1365-3040.1993.tb00842.x

Rambal, S., Ourcival, J.-M., Joffre, R., Mouillot, F., Nouvellon, Y., Reichstein, M., Rocheteau, A., 2003. Drought controls over conductance and assimilation of a Mediterranean evergreen ecosystem: scaling from leaf to canopy. Global Change Biology 9, 18131824. https://doi.org/10.1111/i.1365-2486.2003.00687.x

Rambal, S., Lempereur, M., Limousin, J.M., Martin-StPaul, N.K., Ourcival, J.M., RodríguezCalcerrada, J., 2014. How drought severity constrains gross primary production(GPP) and its partitioning among carbon pools in a Quercus ilex coppice? Biogeosciences 11, 6855-6869. https://doi.org/10.5194/bg-11-6855-2014 
Rana, G., Katerji, N., 2000. Measurement and estimation of actual evapotranspiration in the field under Mediterranean climate: a review. European Journal of Agronomy 13, 125153. https://doi.org/10.1016/S1161-0301(00)00070-8

REVERB NASA web site, 2016. The earth observing system data and information system. URL: http://reverb.echo.nasa.gov/reverb/. (last accessed: 24.12.2020)

Rosch, A., Schmidbauer, H., 2019. WaveletComp 1.1: A guided tour through the R package 58.

Sang, Y.-F., 2013. A review on the applications of wavelet transform in hydrology time series $\begin{array}{llll}\text { analysis. Atmospheric 8-15. } & \text { Research }\end{array}$ https://doi.org/10.1016/i.atmosres.2012.11.003

Sarrazin, F., Hartmann, A., Pianosi, F., Rosolem, R., W ger er, T., 2018. V2Karst V1.1: a parsimonious large-scale integrated vegetation-raci arge model to simulate the impact of climate and land cover change in karst regk $\mathbf{n}_{\mathrm{n}}$. Geoscientific Model Development 11, 4933-4964. https://doi.org/10.5194/g «'-11-4933-2018

Shen, H., Leblanc, M., Frappart, F., Seoa L., O'Grady, D., Olioso, A., Tweed, S., 2017. A

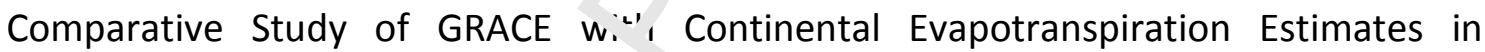
Australian Semi-Arid and Arid b:sins: Sensitivity to Climate Variability and Extremes. Water 9, 614. https://doi.org/!C..? ?

Shuttleworth, W.J., 2007. Puttir ${ }_{i c}$ the "vap" into evaporation. Hydrol. Earth Syst. Sci. 11, 210-244. https://doi.01_/1乞.5194/hess-11-210-2007

Shuttleworth, W.J., 200؟. Eı эpotranspiration Measurement Methods. Southwest Hydrology 7, 22-23.

Simioni, G., Marie, G., Huc, R., 2016. Influence of vegetation spatial structure on growth and water fluxes of a mixed forest: Results from the NOTG 3D model. Ecological Modelling 328, 119-135. https://doi.org/10.1016/j.ecolmodel.2016.02.004

Torrence, C., Compo, G.P., 1998. A Practical Guide to Wavelet Analysis. Bulletin of the American Meteorological Society 79, 61-78. https://doi.org/10.1175/15200477(1998)079<0061:APGTWA>2.0.CO;2

Trajkovic, S., 2005. Temperature-based approaches for estimating reference evapotranspiration. Journal of irrigation and drainage engineering. ASCE 131, 316-323. https://doi.org/10.1061/(ASCE)0733-9437(2005)131:4(316) 
Tritz, S., Guinot, V., Jourde, H., 2011. Modelling the behaviour of a karst system catchment using non-linear hysteretic conceptual model. Journal of Hydrology 397, 250-262. https://doi.org/10.1016/i.jhydrol.2010.12.001

Vuolo, F., Żółtak, M., Pipitone, C., Zappa, L., Wenng, H., Immitzer, M., Weiss, M., Baret, F., Atzberger, C., 2016. Data Service Platform for Sentinel-2 Surface Reflectance and Value-Added Products: System Use and Examples. Remote Sensing 8, 938. https://doi.org/10.3390/rs8110938

Watlet, A., Kaufmann, O., Triantafyllou, A., Poulain, A., Chambers, J.E., Meldrum, P.I., Wilkinson, P.B., Hallet, V., Quinif, Y., Van Ruymbeke, M. Van Camp, M., 2018. Imaging groundwater infiltration dynamics in the karst vadros $<$ sne with long-term ERT monitoring. Hydrol. Earth Syst. Sci. 22, 1563-1592. hi inr.//doi.org/10.5194/hess-22$\underline{1563-2018}$

Weiss, M., Baret, F., 2016. S2ToolBox Level 2 prod ıcts LAI, FAPAR, FCOVER. Version 1.1. INRA 53.

Weiss, M., Jacob, F., Baret, F., Pragnère, A., B` ıchuud, C., Leroy, M., Hautecœur, O., Prévot, L., Bruguier, N., 2002. Evaluation of err el-driven BRDF models for the normalization of Alpilles/ReSeDA POLDER auta. Agronomie 22, 531-536. https://doi.org/10.1051/agro:??는

Zambrano-Bigiarini, M., Rojas, R., 2i13. A model-independent Particle Swarm Optimisation software for model ca.hration. Environmental Modelling \& Software 43, 5-25. https://doi.org/10.1C15/i. =nvsoft.2013.01.004

Zhang, Z., Li, M., Si, २., ᄃค' $\mathrm{g}$, H., 2018. Deep rooted apple trees decrease groundwater recharge in the hi,hland region of the Loess Plateau, China. Science of The Total Environment 622-623, 584-593. https://doi.org/10.1016/i.scitotenv.2017.11.230 


\section{Appendix A - Setting of hydrological model}

\section{A.1 KaRaMel model}

KaRaMel is a hydrological model of karst. Karst hydrosystems are too heterogeneous for a distributed model to be used, so the assumption was to distribute only the most important processes. The distribution of the parameters is deduced with readily available spatial data such as geology, land use, soil characteristics, presence of karstic forms.

The aquifer is gridded in square cells. The same lumped structure is used to represent the flows and water stocks that occur in each cell. There are no wis or exchanges between cells. The first reservoir represents the soil and subsoil, it recei es I recipitation and irrigation, enables evapotranspiration and infiltration to deeper re erv irs. The infiltration feeds two deep reservoirs acting for a slow and fast water tran $\stackrel{f}{n} r$, hat occurs in the aquifer. The sum of the discharge from cells represents the aquifer disc, . . ge.

The KaRaMel and its setting for the Fontaine $d_{c} v$ = ucluse aquifer are described in detail by Ollivier [2019] and Ollivier et. [2020]. When appiied to the Fontaine de Vaucluse watershed 1550 cells are used to represent the $1160 \mathrm{k}_{1},{ }^{2}$ area (most of the cells having a surface about $\left.1 \mathrm{~km}^{2}\right)$.

\section{A.2 KaRaMel and SimpKcE? paı ameters}

The first version of KaRaMel spplied on the Fontaine de Vaucluse aquifer relies on 5 parameters:

- The coefficient $y$ partitions the infiltration between slow and fast flows; the distribution of $\mathrm{x}$ depends on the intrinsic vulnerability indices. The intrinsic vulnerability of the watershed can be low $\left(x_{L}\right)$ or high $\left(x_{H}\right)$.

- $\mathrm{kc}$ and $\mathrm{km}$ are the specific discharge coefficients of reservoirs that control fast flows and slows flow respectively; the distribution of $\mathrm{kc}$ depends on the intrinsic vulnerability indices. The intrinsic vulnerability of the watershed can be low $\left(\mathrm{kc}_{\mathrm{L}}\right)$ or high $\left(k c_{H}\right)$. 
The water holding capacity of the first reservoir of KaRaMel was set equal to the soil available water capacity, explored by soil pit. The implementation of SimpKcET into KaRaMel brings implies the calibration of SimpKcET parameters:

- SAWC add Stands for the water holding capacity of subsoils exploited by plant roots (which can not be measured in soil pits)

- frocks is the fraction of rocks that cover the soil surface.

Both parameters concerned all surfaces with the exception of crop fields for which we can assume a low level of coarse elements near the soil surface and that soil pits cover the full depth of the soil.

\section{A.3 Calibration and validation of the model}

Model parameters were initialized with a three- $y=a$. period (2003-2006), this prevents simulation bias induced by the initialization of th 2 p 'rameters. Model's parameters are calibrated over a three years period, from $S \in \jmath^{+}$er iber 2006 to august 2009. These three years represent a large panel of hydric si.uctio $s$, Table A.3-1. The daily observed discharge sequence from September 2009 to May ?015 is compared with discharge simulation to validate simulation.

Table A.3-1: Statistical descriptic $n$ of daily discharge time series au Fontaine de Vaucluse, depending modelling periods: :armi-up (2003-2006), calibration (2006-2009) and validation (2009-2015).

\begin{tabular}{|c|c|c|c|c|c|c|}
\hline \multicolumn{7}{|c|}{ r. ntaine de Vaucluse daily discharge $\left[\mathrm{m}^{3} . \mathrm{s}^{-1}\right]$} \\
\hline Periods & Min & 1st quantil & Median & Mean & 3rd quantil & Max \\
\hline $2003-2006$ & 4.3 & 6.8 & 9.7 & 13.3 & 16.4 & 82.5 \\
\hline $2006-2009$ & 2.8 & 6.7 & 9.1 & 13.6 & 17.8 & 60.6 \\
\hline $2009-2015$ & 3.9 & 7.9 & 14.0 & 17.5 & 23.5 & 63.0 \\
\hline $2003-2015$ & 2.8 & 7.0 & 9.7 & 13.2 & 16.4 & 82.5 \\
\hline
\end{tabular}


The calibration is performed with the differential evolution optimisation algorithm [Ardia et al., 2011], with an unique objective function, the Kling-Gupta efficiency (KGE). Model performances are evaluated with two additional functions, the root mean square error (RMSE) and the bias.

The KGE function images the Euclidian distance from the ideal point in the scaled space of three components $(r, \beta$ and $\alpha)$. $r$ is the linear correlation coefficient between measurements and simulated flows, $\beta$ the ratio between mean simulated flow and mean observed flow and $\alpha$ the ratio between standard deviation of simulated values and standard deviation of observed values. The KGE reaches 1 for the best adjustments.

$$
K G E=1-\sqrt{(r-1)^{2}+(\alpha-1)^{2}+\left(\frac{n}{r}-1^{2}\right.} \#(A .1)
$$

The simulated ET is evaluated using the root mean squa.॰ error (RMSE) and the mean error (bias) against ET measurements.

$$
\begin{aligned}
R M S E & =\sqrt{\frac{1}{r} \sum_{1}\left(\eta_{0}-v_{s}\right)^{2}} \#(A .2) \\
\text { bias } & =-\frac{1}{L}\left(v_{o}-v_{s}\right) \#(A .3)
\end{aligned}
$$

where $\mathrm{n}$ is the number of simulated lime steps, $\mathrm{v}_{\mathrm{o}}$ the observed variable and $\mathrm{v}_{\mathrm{s}}$ the simulated variable.

Table A.3-2: Calibrated v ılu s of KaRaMel's parameter.

\begin{tabular}{|l|c|c|c|c|c|c|c|}
\cline { 2 - 7 } \multicolumn{1}{c|}{} & $\mathrm{x}_{\mathrm{L}}$ & $\mathrm{x}_{\mathrm{H}}$ & $\mathrm{km}$ & $\mathrm{kc}_{\mathrm{L}}$ & $\mathrm{kc}_{\mathrm{H}}$ & $\mathrm{SAWC}_{\text {add }}$ & $\mathrm{f}_{\text {rocks }}$ \\
\hline $\begin{array}{l}\text { KaRaMel with bucket ET model } \\
\text { [Ollivier et al. 2020] }\end{array}$ & 0.90 & 0.66 & 0.0094 & 0.23 & 0.14 & - & - \\
\hline KaRaMel with SimpKcET & 0.97 & 0.65 & 0.009 & 0.14 & 0.78 & 194 & 0.26 \\
\hline
\end{tabular}




\section{Appendix B: Fontaine de Vaucluse discharge simulations}

In the present study, the Karamel model is applied to the karstic aquifer of the Fontaine de Vaucluse. This enables the simulation of the discharge of the Fontaine de Vaucluse according to the evapotranspiration model used, and to compare the simulations with the observations. The simulations depend on the used evapotranspiration model. Figure B.1, the simulated discharge with KaRaMel + ET bucket model is symbolized by Qbucket, the simulated discharge with KaRaMel + SimpKcET is symbolized by Qsimpkcet and daily discharge observations are symbolized by Qobs. The simulated Fontaine de Vaucluse discharges time series are compared to the observed discharge 0 : or the 2009-215 period.
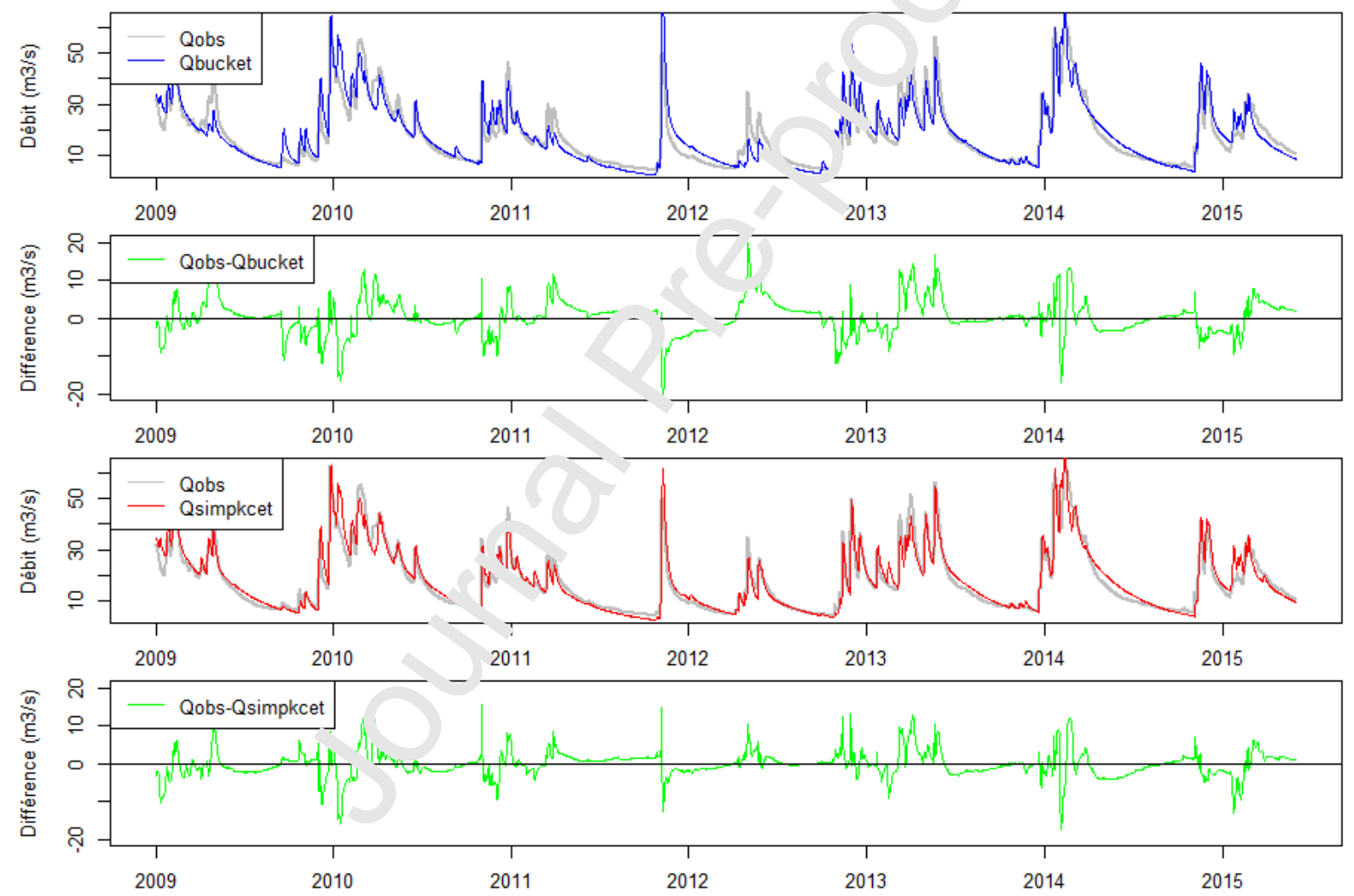

Figure B-1 : Time series of Fontaine de Vaucluse discharges : observed (Qobs) and simulated with KaRaMel + ET bucket model (Qbucket), with KaRaMel + SimpKcET (Qsimpkcet). 
Appendix C: Selected area of the impluvium of Fontaine de Vaucluse with almost homogeneous land cover.
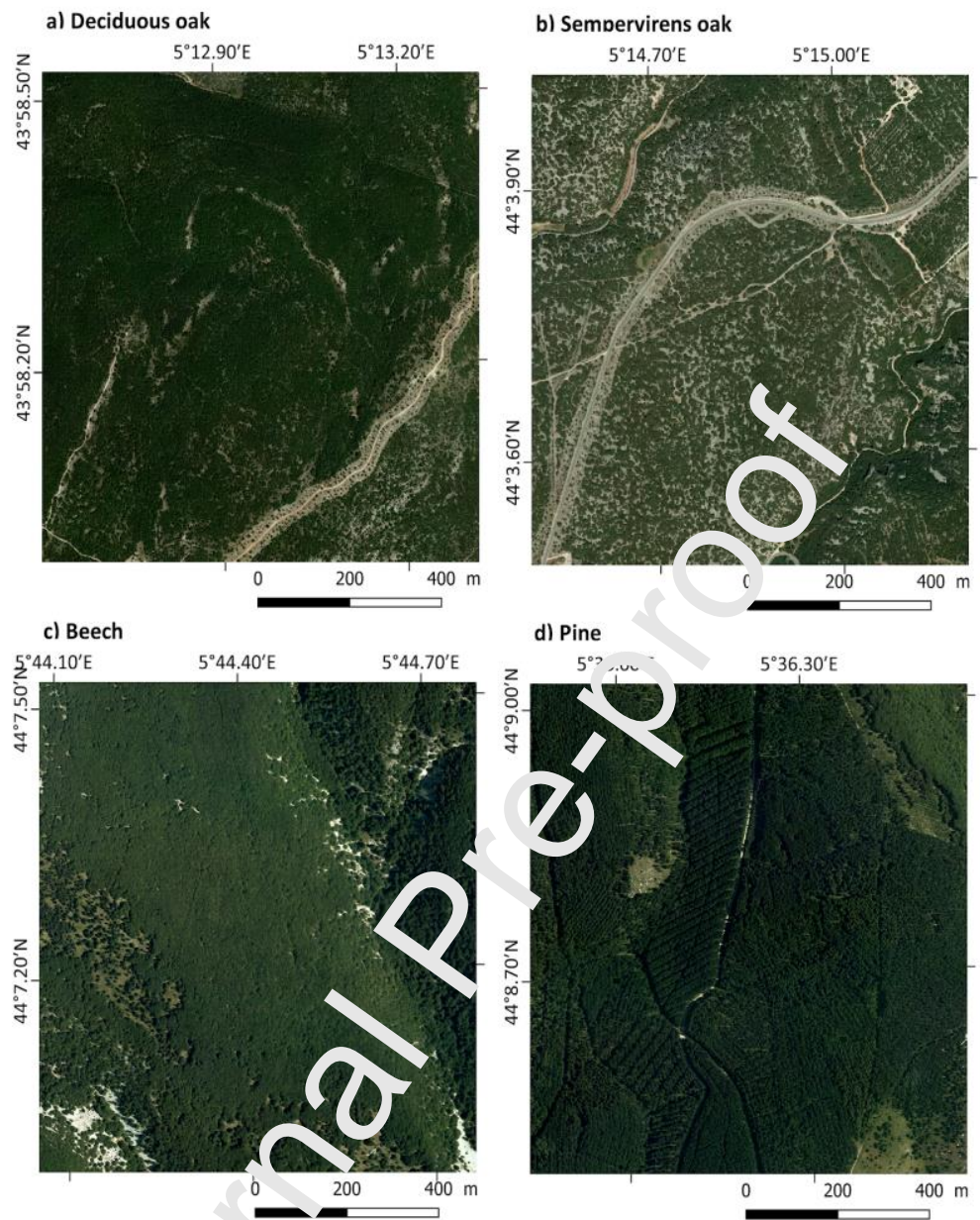

d) Pine
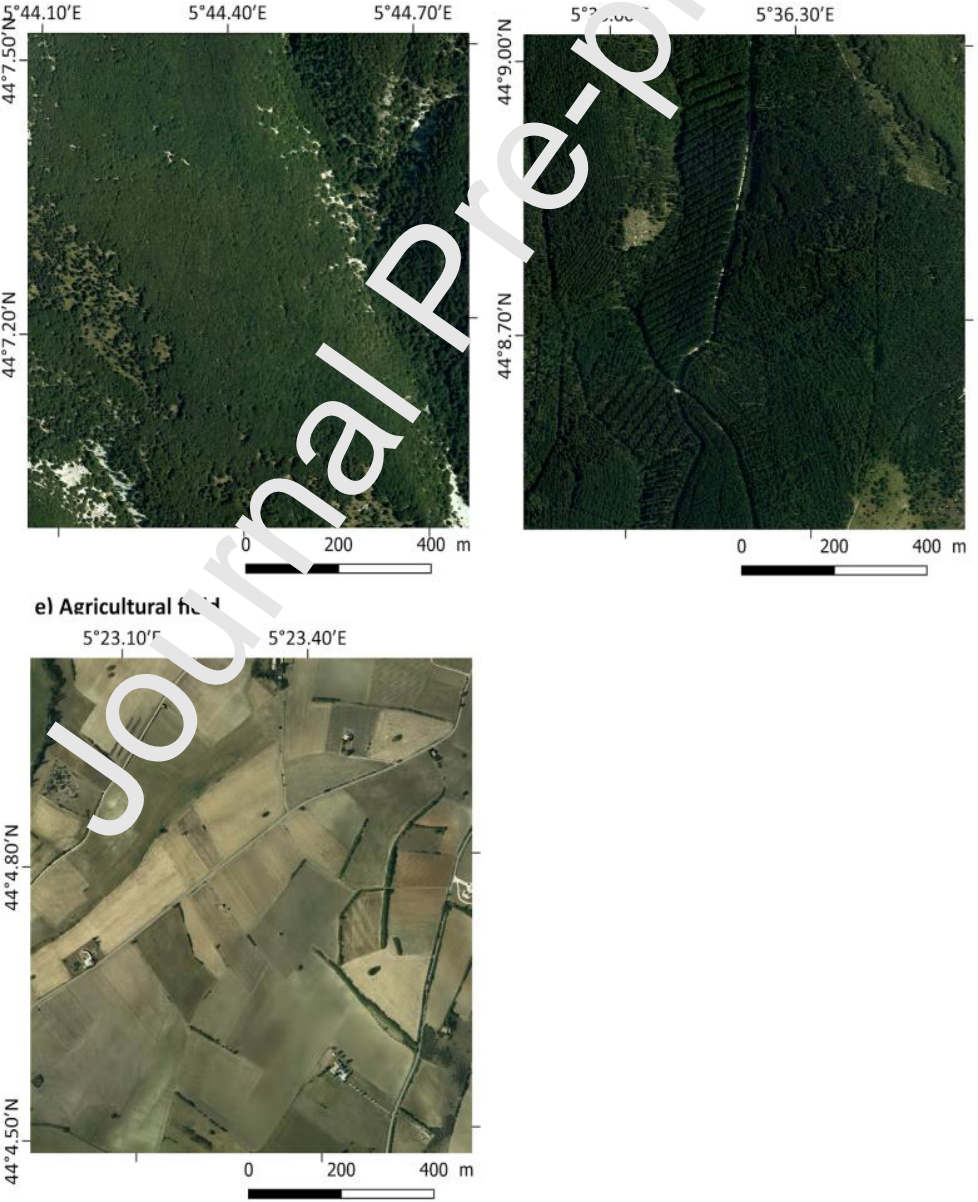

Figure C-1: The areas presented are characterized by a homogeneous vegetation cover at the mesh scale of KaRaMel: a) oak forest Deciduous, b) oak forest Sempervirens, c) beech forest, d) pine forest and e) cultivated fields. 


\section{Appendix D: Details on climate of the studied sites.}

The climate data came from the SAFRAN product of METEO-FRANCE, the French meteorological service [Durand et al., 2009, Quintana-Seguí et al., 2008]. SAFRAN is a weather data source available over France on a grid of $8 \mathrm{~km}$ by $8 \mathrm{~km}$ at the daily scales starting in 1958. SAFRAN product is a surface - atmosphere reanalysis that is built by combining atmospheric model simulations to ground data, we used precipitation and reference evapotranspiration data. SAFRAN reference evapotranspiration was calculated with the Penman-Monteith equation from solar radiation, atmospheric radiation, air temperature, air humidity and wind speed. As in Allen et ᄀ.l. [1998] for the FAO56 methodology, the reference evapotranspiration is estima ad for a well-irrigated grass canopy according to the climatic conditions. Hcw we, parameters used in the implementation of the Penman-Monteith equation ',y i 1 t TEO-FRANCE are slightly different from those of Allen et al. [1998], in particular with iow $>$ r albedo (0.20 instead of 0.23) and lower surface resistance $\left(60 \mathrm{~m} . \mathrm{s}^{-1}\right.$ instead of $7\left(r .1 . \mathrm{s}^{-1}\right)$. This resulted in a higher potential ET than with the FAO56 methodology.

The four test sites are situated in t're typical Mediterranean climate zone, after KöppenGeiger climate classification update $\wedge$, Reck et al. [2020]. Winter is wet and cool, summer is hot and dry. Most of the precic ita: ins occur during autumn and winter. Thus, climate is characterized by frequent sum. 'er droughts lasting at least for 2 months and regularly up to 4 months. Mean annual nrfcipitation and temperatures of hydrological year from September 2000 to $1 \mathrm{u}_{\mathrm{\delta}}$ 'Ist 2016 are (Figure D-1): $981 \mathrm{~mm}$ and $10^{\circ} \mathrm{C}$ over Fontaine de Vaucluse watershed, $686 \mathrm{~mm}$ and $14^{\circ} \mathrm{C}$ in Font-Blanche, $807 \mathrm{~mm}$ and $14.5^{\circ} \mathrm{C}$ in Puechabon, $666 \mathrm{~mm}$ and $15^{\circ} \mathrm{C}$ in Avignon. Mean annual reference evapotranspiration is $1043 \mathrm{~mm}$ for Fontaine de Vaucluse watershed, $1184 \mathrm{~mm}$ in Font-Blanche, $1213 \mathrm{~mm}$ in Puechabon and $1248 \mathrm{~mm}$ in Avignon.

The difference in climatic demands between these sites is mainly related to temperatures. It is interesting to note that years with lowest precipitation amounts are characterized by highest reference evapotranspiration values. The interannual variability of reference evapotranspiration is very low (maximum range around $200 \mathrm{~mm}$ ) compared to precipitation (maximum range around $700 \mathrm{~mm}$ ). However, an increasing trend is visible, which is mainly 
related to the elevation of air temperature, in agreement with the $1 \mathrm{~mm}$.year ${ }^{-1}$ to 2.5 $\mathrm{mm}$.year ${ }^{-1}$ observed over the lower Rhone Valley [Olioso et al., 2013]. No specific trends are detectable on the rain evolution.

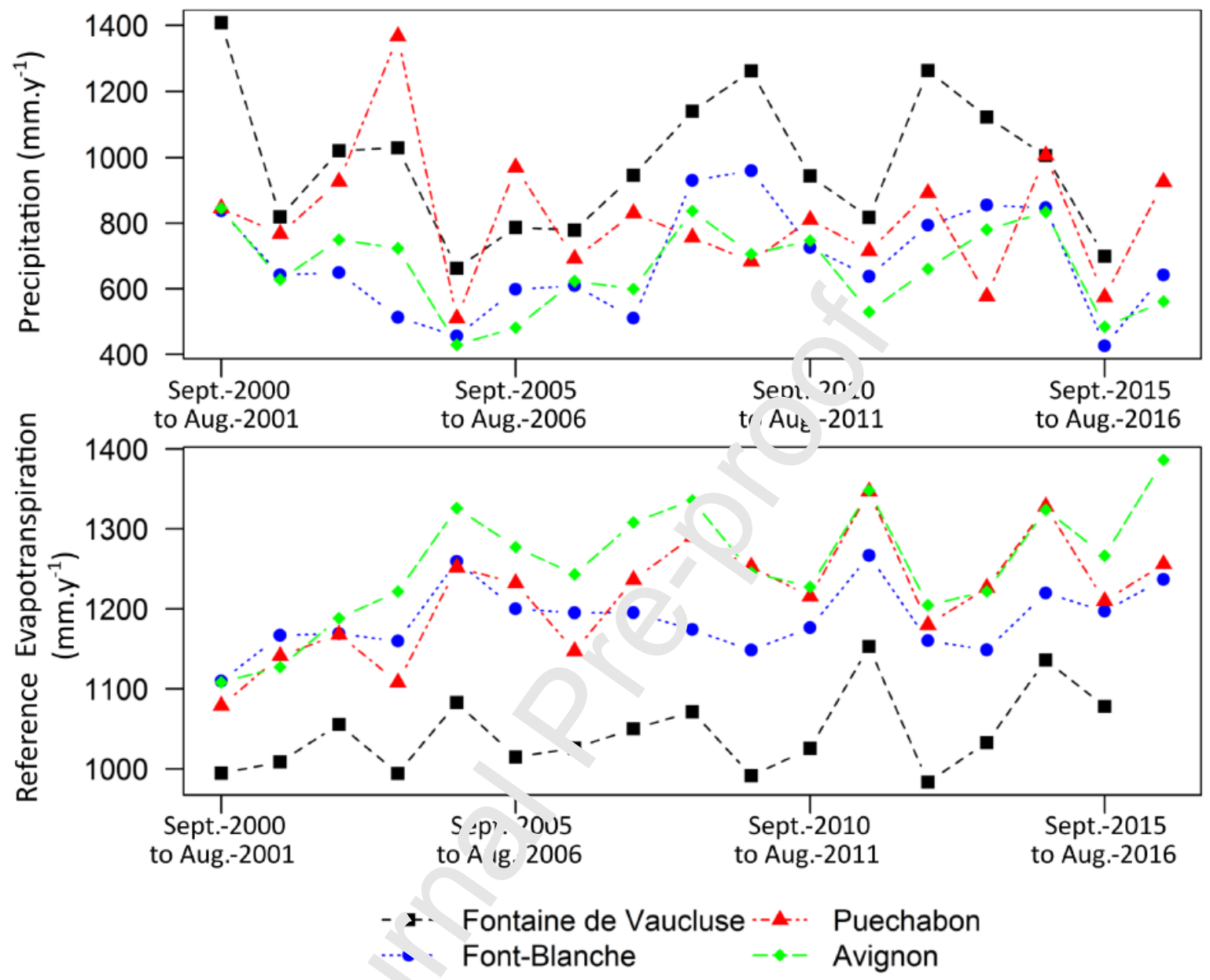

Figure D-1: Annual pecikitation and reference evapotranspiration of studied sites (hydrological year from st ptember to August). 
Article: An evapotranspiration model driven by remote sensing data for assessing groundwater resource in karst system

CRediT author statement.

Chloé Ollivier and Albert Olioso and Simon D. Carrière: conceptualization, methodology, software, writing, review and editing. André Chanzy and Hendrik Davi and Nicolas K. Martin and Guillaume Simioni and Marie Weiss and David Combemale and Olivier Marloie: investigation, data curation, resources. Naomi Mazzilli and Jean-Baptiste Charlier and Gilles Boulet: methodology. Albert Olioso and Christophe Emblanch and Konstantinos Chalikakis: project administration, founding acquisition. 


\section{Declaration of interests}

$\bigotimes$ The authors declare that they have no known competing financial interests or personal relationships that could have appeared to influence the work reported in this paper.

$\square$ The authors declare the following financial interests/personal relationships which may be considered as potential competing interests: 